Review

\title{
The role of key genes and pathways involved in the tumorigenesis of Malignant Mesothelioma
}

\author{
Leonardo Vinícius Monteiro de Assis ${ }^{\text {b,c }}$, Jamille Locatelli ${ }^{\text {b,d }}$, Mauro César Isoldi a,b,d,* \\ ${ }^{a}$ Department of Biological Science, Institute of Exact and Biological Sciences, Brazil \\ ${ }^{\mathrm{b}}$ Laboratory of Hypertension, Campus Universitário Morro do Cruzeiro, Brazil \\ c Pharmacy School, Federal University of Ouro Preto, Minas Gerais, Brazil \\ d Núcleo de Pesquisa em Ciências Biológicas (NUPEB), Universidade Federal de Ouro Preto, Ouro Preto, MG, Brazil
}

\section{A R T I C L E I N F O}

\section{Article history:}

Received 6 December 2013

Received in revised form 20 January 2014

Accepted 24 January 2014

Available online 31 January 2014

\section{Keywords:}

Malignant Mesothelioma

Erionite/SV40

$p 16^{I N K 4 a} / p^{14 A R F}$

NF2

$\mathrm{PI} 3 \mathrm{~K} / \mathrm{AKT}$

Genes and pathways

\begin{abstract}
A B S T R A C T
Malignant Mesothelioma (MM) is a very aggressive cancer with low survival rates and often diagnosed at an advanced stage. Several players have been implicated in the development of this cancer, such as asbestos, erionite and the simian virus 40 (SV40). Here, we have reviewed the involvement of erionite, SV40, as well as, the role of several genes ( $p 16^{\mathrm{INK} 4 a}, \mathrm{p} 14^{A R F}$, NF2, LATS2, SAV, CTNNB1 and among others), the pathways (RAS, PI3K, Wnt, BCL and Hippo), and their respective roles in the development of MM.
\end{abstract}

(c) 2014 Elsevier B.V. All rights reserved.

\section{Contents}

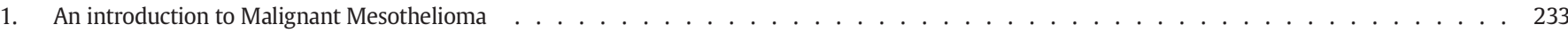

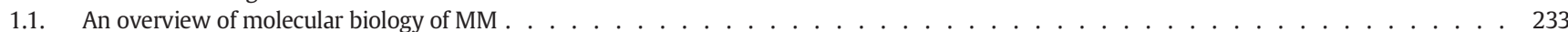

1.2. Asbestos and $\mathrm{MM} \ldots \ldots \ldots \ldots \ldots \ldots$

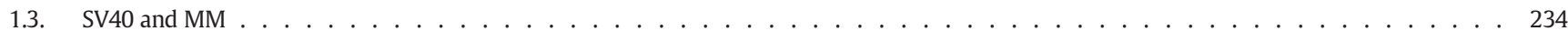

1.4. Erionite and $\mathrm{MM} \ldots \ldots \ldots \ldots \ldots \ldots \ldots \ldots$

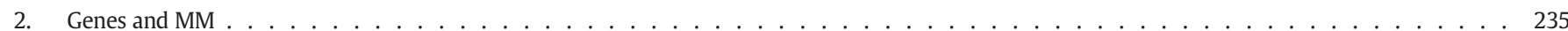

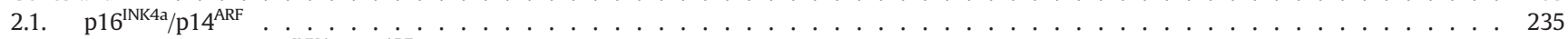

2.1.1. Role of $\mathrm{p} 16^{\mathrm{INK} 4 \mathrm{a}} / \mathrm{p} 14^{\mathrm{ARF}}$ and $\mathrm{MM} \ldots \ldots \ldots \ldots \ldots$

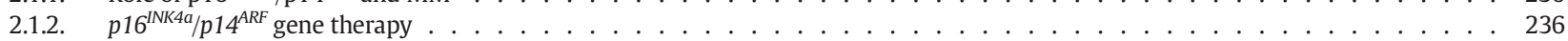

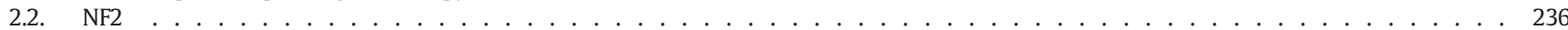

2.2.1. NF2 and MM . . . . . . . . . . . . . . . . . . . . . . . . . . . . . . . . . . . . . . . . . . . . . 237

2.2.2. NF2 gene therapy . . . . . . . . . . . . . . . . . . . . . . . . . . 238

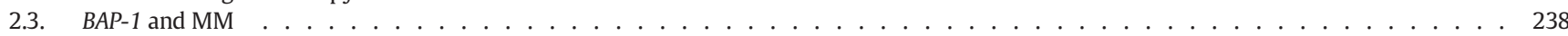

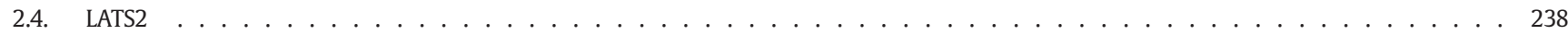

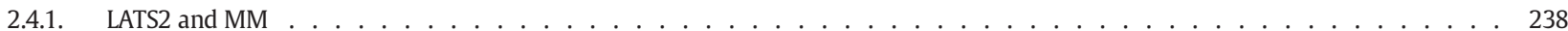

2.5. DNA methylation and $\mathrm{MM} \ldots \ldots \ldots \ldots \ldots \ldots$

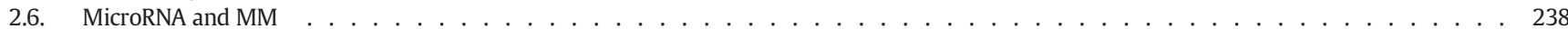

2.7. Other genes and MM . . . . . . . . . . . . . . . . . . . . . . . . . . . . . . 239

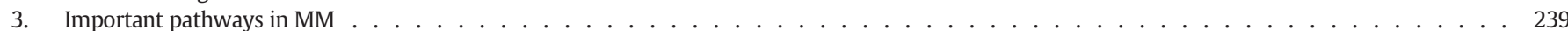

3.1. Receptors tyrosine kinases . . . . . . . . . . . . . . . . . . . . . . . . . . . . 239

3.2. Ras/Raf/MEK/MAPK pathway . . . . . . . . . . . . . . . . . . . . . . . . . . . . . . . . . . 240

3.2.1. Ras/Raf/MEK/MAPK pathway in $\mathrm{MM} \ldots \ldots \ldots \ldots$

\footnotetext{
* Corresponding author at: Departamento de Ciências Biológicas, Universidade Federal de Ouro Preto, Morro do Cruzeiro, 35400-000 Ouro Preto, MG, Brazil. Tel.: +55 3135591693. E-mail address: mauroisoldi@hotmail.com (M.C. Isoldi).
} 
3.3. $\quad \mathrm{PI} 3 \mathrm{~K} / \mathrm{AKT} / \mathrm{mTOR}$ pathway $\ldots \ldots \ldots \ldots \ldots \ldots \ldots$

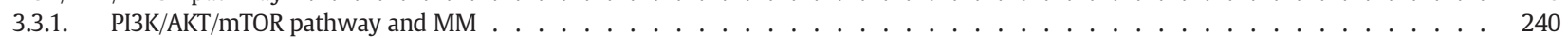

3.3.2. Therapeutic targets . . . . . . . . . . . . . . . . . . . . . . . . . . . . 241

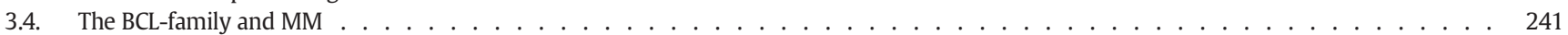

3.4.1. Therapeutic targets . . . . . . . . . . . . . . . . . . . . . . . . . . 241

3.5. The Merlin protein . . . . . . . . . . . . . . . . . . . . . . . . . . . . . . . . . . . . 242

3.5.1. The hippo pathway . . . . . . . . . . . . . . . . . . . . . . . . . . 242

3.5.2. Merlin-hippo pathway and MM . . . . . . . . . . . . . . . . . . . . . . . . . . 242

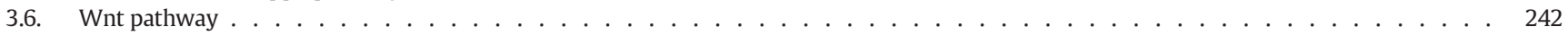

3.6.1. Wnt pathway and $\mathrm{MM} \ldots \ldots \ldots \ldots \ldots$

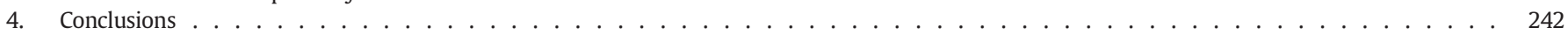

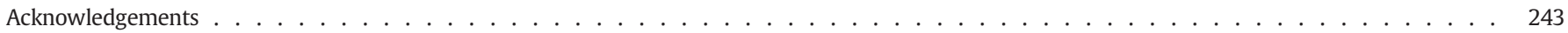

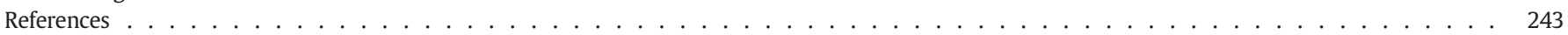

\section{An introduction to Malignant Mesothelioma}

Malignant Mesothelioma (MM) is a slow-growing solid tumor arising from mesothelial cells that can develop in the pleural space, pericardium, peritoneum, tunica vaginalis testis and ovarian epithelium. In its early stage, it is not common for these tumors to suffer metastasis [1]. MM is divided into three categories according to its histological morphology: epithelial, biphasic, and sarcomatoid with median survival period of 18,11, and 8 months, respectively [2]. Moreover, MM displays a long latency period that can take up to 40 years [3]. During this period, there is an accumulation of mutations on several key genes [4]. In the US alone, it is expected 70,000 new cases of MM over the next 20 years [5].

The Malignant Pleural Mesothelioma (MPM) is an aggressive form of cancer that affects the pleura. MPM is known to be very aggressive, and it is often diagnosed at a very advanced stage, which contributes to its very poor prognosis with a median survival of 11 months [6].

It has been more than 50 years since the first study correlating asbestos to the development of MM [7]. Evidence has shown a strong relationship between asbestos exposure and MM [8]. Exposure to simian virus 40 (SV40) [9], erionite [10], and genetic predisposition have been also implicated in the development of MM [11].

\subsection{An overview of molecular biology of $M M$}

MM frequently displays chromosomal loss involving the chromosomes $1,3,4,6,9,13,14$ and 22 [12]. The most common genetic alterations in MM are the homozygous deletion of $p 16^{I N K 4 a}$ and $p 14^{A R F}$ genes. It was found a homozygous deletion of $p 16^{I N K 4 a}$ and $p 14^{A R F}$ in $72 \%$ of MM [13]. In addition, homozygous deletion of the $p 16^{I N K 4 a}$ was present in approximately $75 \%$ of $\mathrm{MM}$, and it was associated with a more aggressive cancer, and with a reduction on survival [14].

The tumor suppressor Neurofibromatosis type II (NF2) has been reported to be altered in MM. NF2 inactivation is a frequent event in MM with rates ranging from 20\% to 60\% [15]. The NF2 gene encodes for the Merlin protein that is associated with the inhibition of several mitogenic signaling pathways [16].

The guardian of the DNA, the protein p53, is encoded by the TP53. The $\mathrm{p} 53$ plays a crucial role in the cellular response to DNA damage, and its expression is lost in many advanced cancers [17]. However, in MM only $20-25 \%$ of the tumors display mutations on TP53, a fairly low rate when comparing to other cancers [18]. In recent studies using MM samples, it was reported an overexpression of p53 in 58.2\% [19], and in $81 \%$ of the cases [20].

The phosphatase and tensin homolog (PTEN), also known as MMAC (mutated in multiple advanced cancers) is a dual lipid and protein phosphatase encoded by the PTEN, which is a tumor suppressor gene (TSG) located on chromosome 10q23. PTEN is known to negatively regulate the AKT pathway; thus the loss of PTEN expression increases AKT pathway activation, which ultimately leads to an uncontrolled cell growth [21-23].
New studies have demonstrated that other genes play important roles in MM. Germline mutation of BAP-1 has been identified in a cancer syndrome predisposing individuals to cancer, including MM; furthermore, it has also been shown $B A P-1$ somatic mutations in MM samples [24]. Likewise, the LATS2 has been recently implicated in the development of MM [25]. DNA methylation and MicroRNA (miRNA) expression have exhibited significant roles in MM, as it is described later on.

The PI3K/AKT/mTOR pathway is altered in MM and plays an important role in cell proliferation, survival and motility in many cancers. In $62 \%$ of MM cell lines, AKT activation was reported [26]. In another study, it was shown that $65 \%$ of human MM species displayed elevated levels of AKT activity [22].

Furthermore, other pathways are dysregulated in MM. The Receptor Tyrosine Kinases (RTKs) drive cell proliferation, survival, differentiation and cell cycle control. Several mechanisms can activate this pathway in cancer providing a good therapeutic option. The overexpression of the epidermal growth factor receptor (EGFR) plays an important role in the progression of several cancers [27]. In a study, the EGFR was present in $44 \%$ of MM samples; however, it is not found to be an independent prognostic factor [28].

The Vascular Endothelial Growth Factor Receptors (VEGF) are a potent inducer of the angiogenesis, and its role in the cancer is well established [29]. High levels of VEGF in MM have been demonstrated, being associated with a worse patient survival [30]. Moreover, the importance of this receptor in regulating the angiogenesis, and tumor progression was established; thus making this pathway as a therapeutic target in MM [31].

The retinoblastoma protein ( $\mathrm{pRb}$ ) pathway plays an important role in apoptosis and cell cycle regulation. Mutation on $\mathrm{pRb}$ is common in many cancers, but not in MM [32]. Nevertheless, the pRb and p53 pathways play an important role in MM. The $p 16^{I N K 4 a}$ and $p 14^{A R F}$ exert effects on the $\mathrm{pRb}$ and on $\mathrm{p} 53$ pathways. The $\mathrm{p} 16^{\mathrm{INK} 4 \mathrm{a}}$ inhibits the cyclin dependent kinases (CDks), preventing the inactivation of $\mathrm{pRb}$; on the other hand, the $\mathrm{p} 14^{\mathrm{ARF}}$ promotes degradation of MDM2, leading then to the stabilization of p53 [33]. Indeed, mutations on TP53 and on RB are not a common event in $\mathrm{MM}$; however mutations and/or alterations on $p 16^{I N K 4 a} / p 14^{A R F}$ are very common. Thus, alterations and/or mutations on $p 16^{I N K 4 a} / p 14^{A R F}$ have the potential to disrupt key cell cycle control pathways.

The BCL-2 family of genes exerts a critical role in the apoptosis process. There are several proteins, which are divided into proapoptotic and antiapoptotic proteins. The proapoptotic proteins are thought to promote the permeability of the mitochondrial membranes, thus promoting the apoptosis; on the other hand, the antiapoptotic proteins are thought to inhibit cells from undergoing programmed death. Studies have found that BCL-2 expression is inversely associated with apoptosis; however this protein is not frequently expressed in MM $[34,35]$. High levels of $\mathrm{BCL}-\mathrm{XL}$ are a common event in MM; however, downregulation of BCL-XL increases apoptosis and the cystostatic effects of cisplatin and gemcitabine [36]. 
The hippo pathway controls cell proliferation, growth, differentiation and death [37], and it has been implicated in the development of MM $[38,39]$. The Wnt pathway plays a fundamental role in the determination of cell fate, proliferation, polarity, and cell death during embryonic development [40]. The Wnt signaling pathway has been reported in MM [41]. Therefore, it is clear that there are several players, genes, and pathways involved in MM, all of which are described in depth in the following sections.

\subsection{Asbestos and MM}

We have recently reviewed the role of asbestos in MM and its carcinogenic mechanisms, which are summarized in Fig. 1. In this same work, we have also reviewed the roles of PTEN and TP53 in the development of MM [42].

\subsection{SV40 and MM}

The Simian virus 40 (SV40) is a DNA monkey virus that was present in contaminated polio vaccines produced from 1955 to 1978. It is believed, that this is the most likely route of SV40 transmission into humans [43]. Furthermore, the SV40 has been implicated in MM [44]. It was observed that specific SV40 viral sequences were present in 57\% of epithelial invasive MM [45]. In another study, initially, it was reported the presence of SV40 in 60\% of MM samples; then later on, it was shown that these findings were incorrect due to plasmid contamination, and that only $6 \%$ of the positive samples had the presence of SV40 DNA [46]. Recently, an Italian study in a hyperendemic area of MM has detected SV40 DNA in 22\% of the MM tumors with a low viral load [47].

Negative results have also been published. In a study, the authors have reported that SV40 was absent in 69 (100\%) MM tumors [9]. Another study has reached the similar conclusion [48]. Recently, no SV40 was detected in Korean MM samples [49], and similar conclusions has reached a recent study in Slovenia [50]. Thus, these contradictions in the literature have caused a huge controversy regarding the role of SV40 in MM. Until now, at least 50 laboratories have detected the presence of SV40 in human tumors using a great variety of molecular biology techniques; and thus raising even more the controversy about the role of SV40 in MM [51]. For instance, 100\% of animals injected with SV40 in the pleural tissue developed MM within 6 months [52], thus showing a relationship between SV40 and MM, at least in animal studies. Besides, the relationship and the controversy between SV40 and MM have been extensively addressed by Qi et al. [51].

However, an animal study has shown that SV40 alone was not able to cause MM, only asbestos exposure caused $20 \%$ of MM, and remarkably, asbestos and SV40 together caused 90\% of MM in hamsters. This study has shown that lower amounts of asbestos may cause MM in animals infected by SV40 [43], and similar conclusions have been found by another study [53]. Therefore, these studies indicate that the levels of asbestos exposure that are considered "safe" for the whole population, may not be for those who were previously exposed to SV40. Lastly, a recent study has shown that long-term exposure to asbestos in SV40 infected cells generates resistance to chemotherapyinduced apoptosis [54].

The mechanisms behind SV40 carcinogenic activity are indeed complex, and not fully understood. The SV40 oncogenic activity rests on the production of two major proteins: the small t antigen (tag) and the large T antigen (TAG). It is known that TAG is able to inactivate several tumor suppressor genes, such as TP53 and RB. These genes encode key proteins to the cell cycle checkpoints, and the loss of these proteins leads to uncontrolled cell proliferation [53]. Furthermore, the tag protein inhibits the cellular phosphatase $2 \mathrm{~A}$ ( $\mathrm{PP} 2 \mathrm{~A})$, which is involved in the dephosphorylation of many protein substrates, including elements of the MAPK pathway (Fig. 1). Consequently, the loss of PP2A by tag may alter the activity of several phosphoproteins [55]. In addition to these classical mechanisms, it was recently shown that TAG-p53-pRb-p300 complex regulates the transcription of the insulin-like growth factor I (IGF-1) gene by binding to the IGF-1 promoter. In other words, there

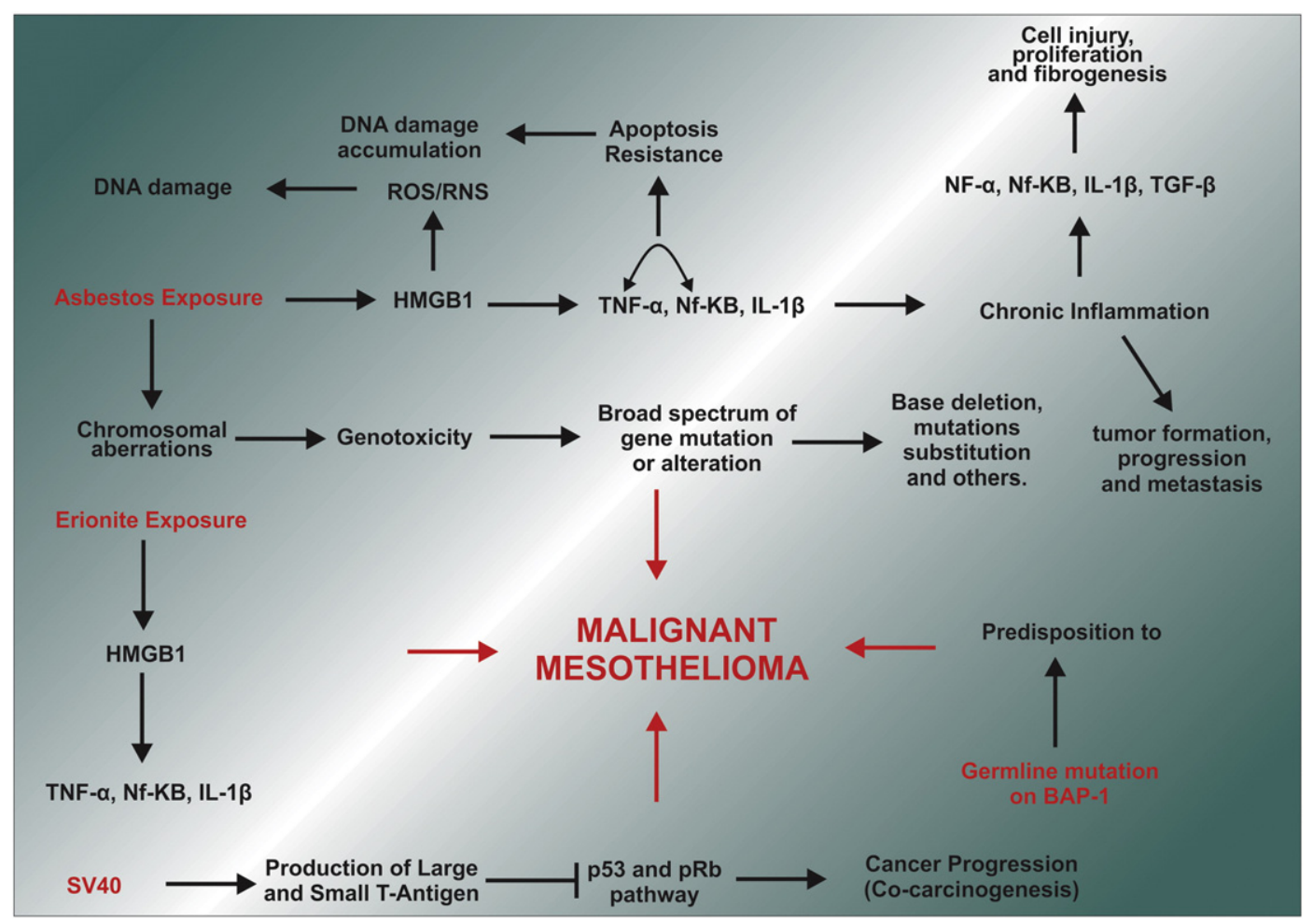

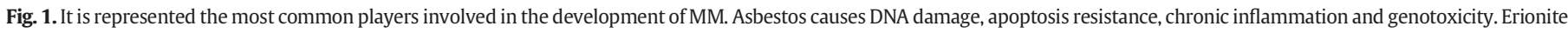

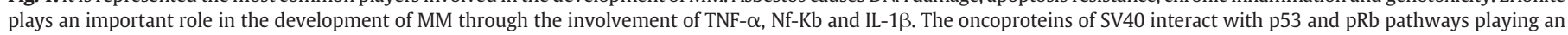
important role as a co-carcinogenic factor in MM. Lastly, germline mutation on BAP-1 confers predisposition to MM. 
is an increase of IGF-1 production, which leads to enhanced cell growth [56]. Moreover, it has also been shown the involvement of SV40 in the expression of VEGF [57], and in the increase of telomerase activity in MM cells [58].

Taken altogether, it is still not clear the direct carcinogenic effects of SV40 in MM in humans; however, it is widely accepted the role of SV40 as a co-carcinogenic player in association with asbestos in the development of MM $[51,59]$.

\subsection{Erionite and $M M$}

It has been reported cases of MM without any previous known contact with asbestos particles, in other words, not all MM cases are etiologically related to asbestos exposure [60]. Indeed, it is often wrongly assumed that only asbestos causes MM, but in fact, other agents have been implicated in the development of MM, among these agents, the mineral erionite.

The erionite is a fibrous form of the zeolite group of minerals, which is several times more carcinogenic than crocidolite asbestos in causing MM [10,61]. The relationship between erionite and MM was first studied in some villages in Turkey, where a strong correlation between erionite exposure and MM incidence was found $[62,63]$. The names of the villages first described were Karain, Tuzköy and Sarihidir, and at that time, there were approximately 5000 people living in these villages. The mortality rate due to MPM among Karain village was 8 deaths/ 1000 inhabitants/year; in addition to $52 \%$ of deaths related to MM from 1970 to 1994 [64]. Therefore, these studies have shown that erionite is a strong inducer of MM in humans.

Until recently, erionite exposure was believed to be a health problem only in Turkey; however, this has changed dramatically with the discovery of the first erionite related MM case in the US [65], and also with the first reported case of a patient with erionite-associated pleural mesothelioma in North America [66]. Astonishing evidence has shown that over the past 30 years more than 300 miles of road was surfaced with erionite-containing gravel in Dunn County, North Dakota, USA. In this same study, it has been reported that the airborne concentration of erionite in several places was equal or exceeded the concentrations found in Turkish villages known to have a high incidence of MM induced by erionite [67].

Consequently, asbestos and erionite likely share the mechanisms of toxicity and carcinogenesis [68,69]; in addition, erionite is able to induce the transformation of human mesothelial cells (MET5-A), but on the other hand, asbestos is not able to cause such transformation [70]. Furthermore, it has been speculated that the HMGB1 (High mobility group box 1) (Fig. 1) is a critical initiator of the chronic inflammation in erionite exposed individuals with the release of IL-1 $\beta$ and TNF- $\alpha$ [69]. It has been reported that erionite activates NLRP3 inflammasome in human mesothelial cells, which is associated with the release of IL-1 $\beta$, IL-6, IL-8 and VEGF, and with the activation of an autocrine feedback loop modulated via the IL-1 receptor. Likewise, it has been shown that IL-1 receptor blocking may play an important role in inhibiting MM growth and progression [71].

\section{Genes and MM}

\section{1. $p 16^{I N K 4 a} / p 14^{A R F}$}

Located at the 9p21 chromosome, the $p 16^{I N K 4 a} / p 14^{A R F}$ (also known as CDKN2A/ARF) are important tumor suppressor genes, which encode two functionally unrelated proteins, the p16 $6^{\text {INK4a }}$ and the p14 ${ }^{\text {ARF }}$ (also known as p19ARF in mice). These proteins have unique first exons $(1 \alpha$ and $1 \beta$ ), but share exons 2 and 3 , which are translated from an alternative reading frame with no amino acid homology [72]. The same locus harbors another tumor suppressor gene (TSG) called $p 15^{I N K 4 B}$ (also known as CDKN2B), which encodes the protein $\mathrm{p} 15^{\mathrm{INK} 4 \mathrm{~B}}$, a CDK (cyclin-dependent kinase) inhibitor known to be induced by TGF [73].

The $\mathrm{p} 16^{\mathrm{INK} 4 \mathrm{a}}$ is a CDK inhibitor, and acts by inhibiting the CDKmediate hyperphosphorylation that leads to $\mathrm{pRb}$ inactivation, while $\mathrm{p} 14^{\mathrm{ARF}}$ regulates $\mathrm{p} 53$ function by inhibiting $\mathrm{p} 53$ degradation through MDM2 interaction [27,74]. p16 $6^{\mathrm{INK} 4 \mathrm{a}}$ maintains $\mathrm{pRb}$ in its active hypophosphorylated form by disrupting the CDK4/6-cyclin D complex, leading to $\mathrm{G}_{1}$-phase cell cycle arrest (Fig. 2). Thus, both $\mathrm{p} 16^{\mathrm{INK} 4 \mathrm{a}}$ and

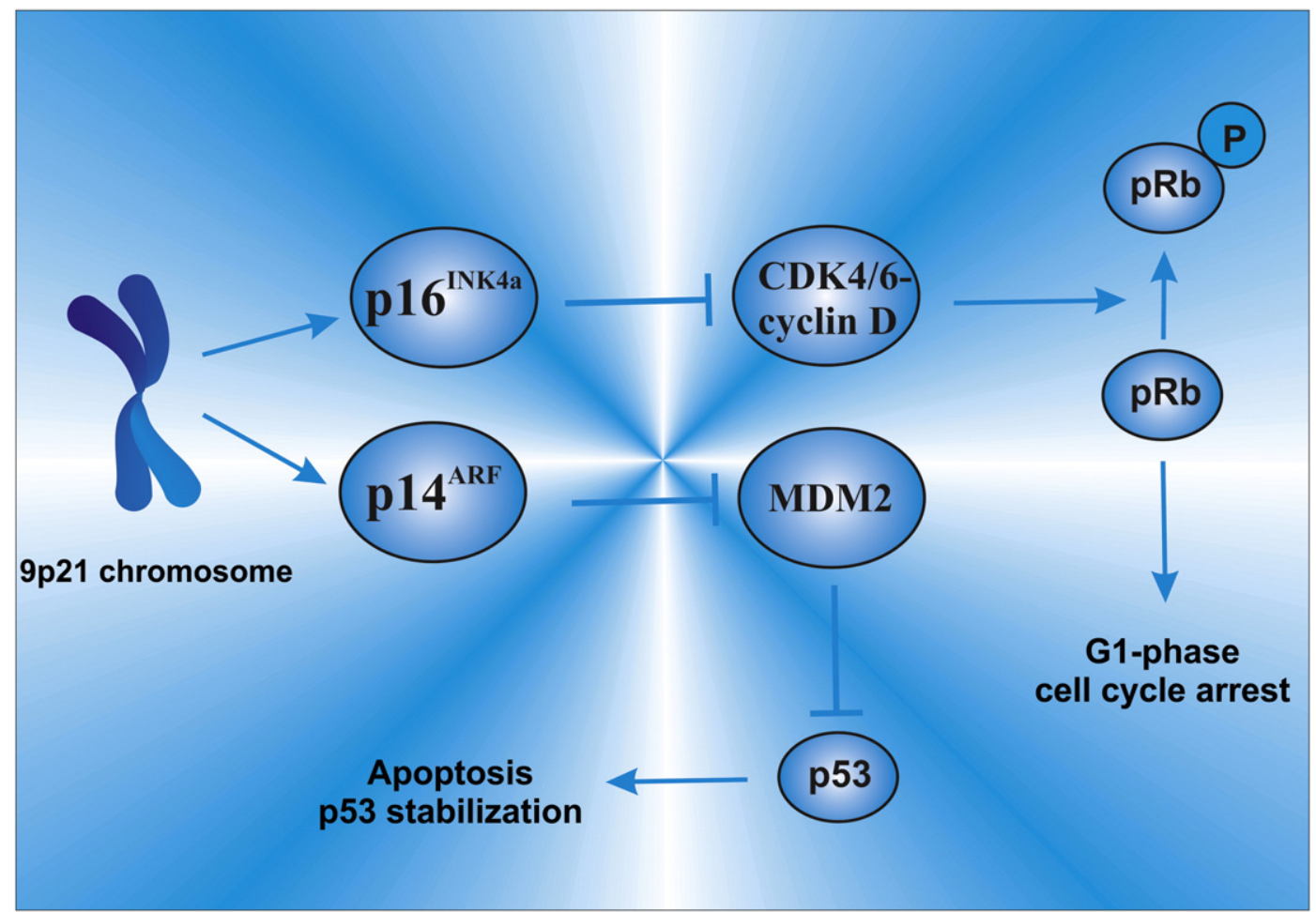

Fig. 2. The role and function of $\mathrm{p} 16^{\mathrm{INK} 4 \mathrm{a}} / \mathrm{p} 14^{\mathrm{ARF}}$ in the cell cycle control, apoptosis and their interaction with other key regulatory cell cycle proteins. 
$\mathrm{p} 14^{\mathrm{ARF}}$ are key cell cycle regulators due to their role in the p53 and the pRb pathways [75]. Therefore, genetic defects in the $p 16^{I N K 4 a} / p 14^{A R F}$ are able to lead to loss of function on both $\mathrm{p} 53$ and $\mathrm{Rb}$ pathways, which are key players to a regulated cell cycle control (Fig. 3).

\subsubsection{Role of $p 16^{I N K 4 a} / p 14^{A R F}$ and $M M$}

The $p 16^{I N K 4 a} / p 14^{A R F}$ have been implicated in the development of human cancers [76-78]. This is no different in MM, in which these genes have been extensively shown to be inactive. It has been shown homozygous deletions of $p 16^{I N K 4 a}$ in $85 \%$ of mesothelioma cell lines [79], abnormal $\mathrm{p} 16^{\mathrm{INK} 4 \mathrm{a}}$ expression in all primary mesothelioma specimens and cell line [32], and codeletion of $p 16^{I N K 4 a}$ and $p 15^{I N K 4 B}$ in $72 \%$ of primary mesotheliomas [13]. Regarding the histological type, MM epithelioid samples have shown approximately $70 \%$ of $p 16^{I N K 4 a} / p 14^{A R F}$ homozygous deletions; the sarcomatoid and biphasic have shown approximately $100 \%$ of homozygous deletions [80-83]. Loss of the 9p21 locus was observed in 32\% of MM cases. Furthermore, intermediate methylation values were observed in the promoter region of the $p 16^{I N K 4 a} / p 14^{A R F}$ in MM samples with no changes on the prognosis [84]. Further studies are summarized in Table 1.

Genetic engineering has been a great asset in better understanding the functions of these genes. Thus, a knockout mouse for $p 19^{A R F}$, but expressing $p 16^{I N K 4 a}$ develops tumors early in life [85]. Similar results have been found using knockout mice for $p 16^{I N K 4 a}$ [86]. Not surprisingly, knockout mice for both $p 16^{I N K 4 a} / p 19^{A R F}$ were more prone to the spontaneous development of tumors at an early age, and highly sensitive to carcinogenic treatments [87].

Although, several studies have shown loss of $p 16^{I N K 4 a} / p 14^{A R F}$ in MM, only recently a knockout mice model for $p 19^{A R F}$ have been developed, showing that the inactivation of this gene plays a significant role in driving MM pathogenesis [88]. Furthermore, an interesting study has shed more light on the role of both genes in the development of MM related to asbestos exposure. In this study, mice deficient for p16 $6^{I N K 4 a(+/-)}, p 19^{A R F}(+/-)$, and those with double deficiency $\left(p 16^{I N K 4 a(+/-)} / p 19^{A R F(+/-)}\right)$ were exposed to asbestos. The mice p16 ${ }^{I N K 4 a(+/-)} / p 19^{A R F(+/-)}$ displayed accelerated asbestos-induced MM in comparison to $p 16^{I N K 4 a(+/-)}$ or $p 19^{A R F(+/-)}$ mice alone. The p16 $6^{I N K 4 a(+/-)}$ mice displayed bi-allelic inactivation of $p 16^{I N K 4 a}$, loss of the $p 14^{A R F}$ or $\mathrm{p} 53$ expression, and frequent loss of $p 15^{I N K 4 b}$; on the other hand, mice $p 19^{A R F(+/-)}$ exhibited loss of $p 19^{A R F}$ expression, but no loss of $p 16^{I N K 4 a}$ or $p 15^{I N K 4 b}[89]$.

Thus, this study clearly shows that both genes play significant, and not redundant roles in MM, and their inactivation increases the tumorigenesis caused by asbestos exposure. Another interesting finding of this study was that p53 remained functional even in the absence of $p 19^{A R F}$, thus showing that $p 19^{A R F}$ loss contributes to MM progression via $\mathrm{p} 53$ independent pathway(s) [89], as it has been confirmed by other studies $[36,88]$.

\subsection{2. $p 16^{I N K 4 a} / p 14^{A R F}$ gene therapy}

Gene therapy has been growing considerably in the last decade especially in Mesothelioma due to the poor response to the traditional chemotherapy. It has been shown previously, that loss of the $p 16^{I N K 4 a} / p 14^{A R F}$ is the most common event in MM, and thus therapies targeting the re-expression of these genes in mesothelioma cell lines have shown interesting results. It has been demonstrated, that the transduction of $p 16^{I N K 4 a}$ expressing adenovirus in mesothelioma cells resulted in cell cycle arrest, inhibition of pRb phosphorylation, diminished cell growth, and eventual death of the transduced cells [90]. Likewise, in a human mesothelioma xenografts study, the reexpression of the $p 16^{I N K 4 a}$ led to: an increase in survival [91]; an increase in p53 protein levels; a reduction on the phosphorylation of $\mathrm{pRb}$, as well as $\mathrm{G}_{1}$-phase cell cycle arrest and apoptotic cell death [12]. The re-expression of $p 16^{I N K 4 a} / p 14^{A R F}$ using different vectors did not show better results in comparison to the single re-expression of the $p 16^{I N K 4 a}$ [92]. Taken altogether, gene therapy targeting both genes seems to have promising results. The clinical gene therapy trials for mesothelioma has been recently revised elsewhere [93].

\subsection{NF2}

The Neurofibromatosis type 2 (NF2) is a dominantly inherited tumor predisposition syndrome characterized by the development of bilateral vestibular schwannomas of the eighth cranial nerve, and by other brain

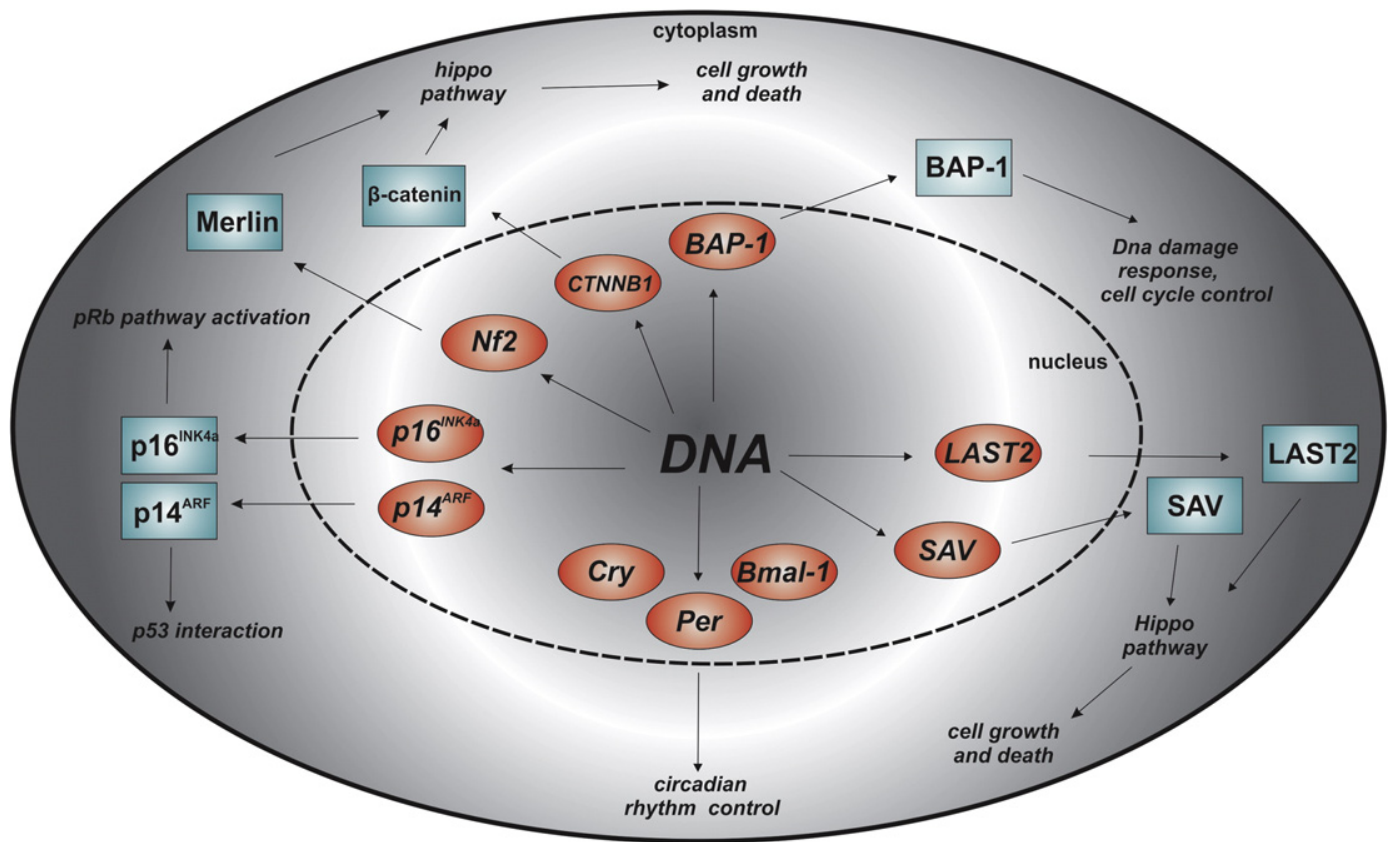

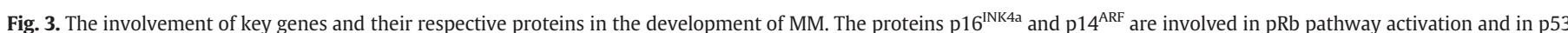

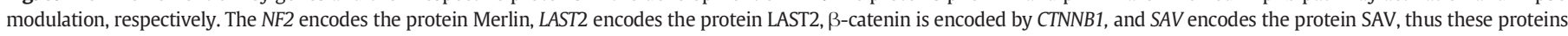

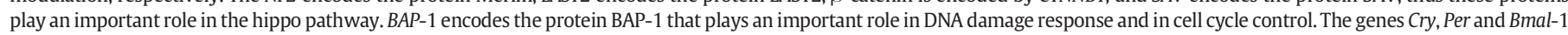
are key players responsible for regulating the circadian rhythm control. 
Table 1

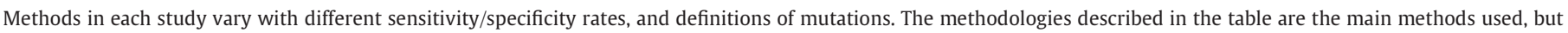

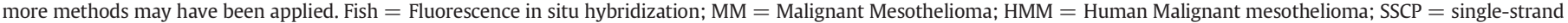
conformation polymorphism.

\begin{tabular}{|c|c|c|}
\hline \multicolumn{3}{|l|}{ Evaluation of $p 16^{I N K 4 a} / p 14^{A R F}$ expression in MM } \\
\hline Study & Methodology & Main results \\
\hline $\begin{array}{l}\text { p16 alterations and deletion mapping of 9p21-p22 } \\
\text { in Malignant Mesothelioma [79] }\end{array}$ & $\begin{array}{l}\text { Southern Blot and PCR. } \\
40 \text { cell lines and } 23 \text { primary tumors. }\end{array}$ & $\begin{array}{l}\text { Homozygous deletion of } p 16^{I N K 4 a} \text { in } 34(85 \%) \text { cell lines } \\
\text { and in } 5(22 \%) \text { of primary tumors }\end{array}$ \\
\hline p16 deletion in sarcomatoid tumors of the lung and pleura [249] & $\begin{array}{l}\text { FISH } \\
\text { Sarcomatoid malignant mesotheliomas samples }\end{array}$ & $\begin{array}{l}\text { Deletion of } 9 \text { p21 in } 26 \text { of } 32(81 \%) \text { in malignant } \\
\text { mesotheliomas }\end{array}$ \\
\hline $\begin{array}{l}\text { Codeletion of } p 15 \text { and } p 16 \text { in primary malignant } \\
\text { mesothelioma [13] }\end{array}$ & $\begin{array}{l}\text { FISH } \\
\text { Primary mesotheliomas samples }\end{array}$ & $\begin{array}{l}\text { Codeletion of } p 15^{I N K 4 b} \text { and } p 16^{I N K 4 a} \text { in } 72 \% \text { of } \\
\text { mesotheliomas }\end{array}$ \\
\hline $\begin{array}{l}\text { Genomic profiling of malignant pleural mesothelioma } \\
\text { with array-based comparative genomic hybridization shows } \\
\text { frequent non-random chromosomal alteration regions including } \\
\text { JUN amplification on } 1 \mathrm{p} 32 \text { [247] }\end{array}$ & $\begin{array}{l}\text { Genome-wide array-based CGH, RT-PCR } \\
9 \text { MPM cell lines and } 17 \text { MPM samples; }\end{array}$ & $\begin{array}{l}p 16^{I N K 4 a} / p 14^{A R F} \text { deletion was found in } 7(41 \%) \text { MPM } \\
\text { samples and in } 9(100 \%) \text { MPM cell lines. }\end{array}$ \\
\hline $\begin{array}{l}\text { Diagnostic importance of 9p21 homozygous deletion in malignant } \\
\text { mesotheliomas [83] }\end{array}$ & $\begin{array}{l}\text { FISH } \\
\text { Pleural mesothelioma and Peritoneal mesothelioma } \\
\text { samples }\end{array}$ & $\begin{array}{l}\text { Homozygous deletion of the } 9 \mathrm{p} 21 \text { in } 35 \text { of } 52 \text { cases } \\
\text { ( } 67 \% \text { ) of pleural mesothelioma and in } 5 \text { of } 20 \text { cases of } \\
\text { peritoneal mesothelioma ( } 25 \%)\end{array}$ \\
\hline $\begin{array}{l}\text { Establishment and characterization of four malignant pleural } \\
\text { mesothelioma cell lines from Japanese patients [248] }\end{array}$ & $\begin{array}{l}\text { PCR, SSCP analysis and Western Blot } \\
4 \text { HMM cell lines }\end{array}$ & $p 16^{I N K 4 a} / p 14^{A R F}$ in all four HMM cell lines \\
\hline $\begin{array}{l}\text { 9p21 deletion in the diagnosis of malignant mesothelioma } \\
\text { in serous effusions additional to immunocytochemistry, } \\
\text { DNA-ICM, and AgNOR analysis [81] }\end{array}$ & $\begin{array}{l}\text { FISH } \\
\text { Malignant mesothelioma patient samples }\end{array}$ & $\begin{array}{l}\text { 9p21 homozygous deletion in } 48.5 \% \text {, heterozygous } \\
\text { deletion in } 36.4 \%\end{array}$ \\
\hline $\begin{array}{l}\text { Promoter methylation of RASSF1A, RARÎ }{ }^{2} \text { and DAPK predict } \\
\text { poor prognosis of patients with malignant mesothelioma [84] }\end{array}$ & $\begin{array}{l}\text { Nested methylation-specific PCR DNA of mesothelioma } \\
\text { patients }\end{array}$ & $\begin{array}{l}p 16^{I N K 4 a} \text { and } p 14^{A R F} \text { promoter region methylation } \\
\text { in } 28.2 \% \text { and } 44.2 \% \text {, respectively }\end{array}$ \\
\hline $\begin{array}{l}\text { Morphology of 9p21 homozygous deletion-positive pleural } \\
\text { mesothelioma cells analyzed using fluorescence in situ } \\
\text { hybridization and virtual microscope system in effusion } \\
\text { cytology [250] }\end{array}$ & $\begin{array}{l}\text { FISH } \\
15 \text { epithelioid MPM }\end{array}$ & $\begin{array}{l}12 \text { positive for a homozygous deletion and } 3 \text { positive for } \\
\text { both homozygous and heterozygous deletions } \\
\text { with a predominantly heterozygous pattern }\end{array}$ \\
\hline $\begin{array}{l}\text { 9p21 deletion in the diagnosis of malignant mesothelioma, } \\
\text { using fluorescence in situ hybridization analysis [82] }\end{array}$ & $\begin{array}{l}\text { FISH } \\
\text { Malignant mesothelioma patient samples }\end{array}$ & 9p21 deletion in 35 of 40 (88\%) cases with MM \\
\hline $\begin{array}{l}\text { Genomic gains and losses in malignant mesothelioma } \\
\text { demonstrated by FISH analysis of paraffin-embedded } \\
\text { tissues [249] }\end{array}$ & $\begin{array}{l}\text { FISH } \\
\text { Malignant mesothelioma patient samples }\end{array}$ & $\begin{array}{l}\text { Loss } p 16^{I N K 4 a} / p 14^{A R F} \text { in epithelioid } 23 / 30(77 \%) \text { and } \\
\text { biphasic/sarcomatoid } 12 / 12(100 \%) \text { mesotheliomas }\end{array}$ \\
\hline $\begin{array}{l}\text { Immunohistochemical analysis of the p16INK4 } \\
\text { cyclin-dependent kinase inhibitor in malignant } \\
\text { mesothelioma [32] }\end{array}$ & $\begin{array}{l}\text { Immunohistochemical analysis and Immunoblot. } \\
\text { Primary thoracic mesotheliomas and mesothelioma } \\
\text { cell lines }\end{array}$ & $\begin{array}{l}\text { Abnormal p } 16^{\mathrm{INK} 4 \mathrm{a}} \text { protein expression in } 12 \text { of } \\
12 \text { primary mesothelioma specimens and in } 15 \text { of } \\
15 \text { mesothelioma cell lines }\end{array}$ \\
\hline $\begin{array}{l}\text { Homozygous deletion of CDKN2A/ARF and codeletion of the } \\
\text { methylthioadenosine phosphorylase gene in the majority } \\
\text { of pleural mesotheliomas [247] }\end{array}$ & $\begin{array}{l}\text { FISH } \\
\text { Pleural mesothelioma samples }\end{array}$ & $\begin{array}{l}p 16^{I N K 4 a} / p 14^{A R F} \text { homozygous deletion in } 70 \text { samples } \\
\text { ( } 74 \%) . \text { Homozygous loss of } p 16^{I N K 4 a} / p 14^{A R F} \text { in } 49 \\
\text { of } 71 \text { epithelial ( } 70 \%), 16 \text { of } 19 \text { biphasic ( } 89 \%) \\
\text { and } 5 \text { of } 5 \text { sarcomatous ( } 100 \% \text { ) mesotheliomas. }\end{array}$ \\
\hline
\end{tabular}

tumors, including meningiomas and ependymomas [94]. This syndrome is caused by mutations and lack of expression of the tumor suppressor gene NF2 (Fig. 3), which is located on chromosome 22q12, and encodes the 595 amino acid protein called Merlin (Moesin-ezrin-radixin-like protein) [95].

\subsubsection{NF2 and MM}

In 1995, two groups first demonstrated that this gene was mutated in approximately $40-50 \%$ of $\mathrm{MM}$, and its inactivation was important in the tumorigenesis of MM $[95,96]$. Follow-up studies have confirmed the importance of this gene in the development of $\mathrm{MM}$, and are

Table 2

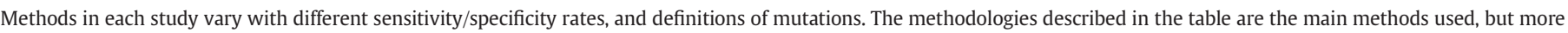

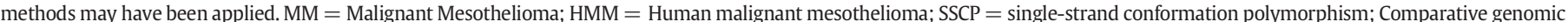
hybridization $(\mathrm{CGH})$

\begin{tabular}{|c|c|c|}
\hline \multicolumn{3}{|l|}{ Evaluation of NF2 expression in MM } \\
\hline Study & Methodology & Main results \\
\hline $\begin{array}{l}\text { Frequent mutations of NF2 and allelic loss from } \\
\text { chromosome band 22q12 in malignant mesothelioma: } \\
\text { Evidence for a two-hit mechanism of NF2 inactivation [251] }\end{array}$ & $\begin{array}{l}\text { Western blot and DNA sequence analyses } \\
25 \text { MM cell lines }\end{array}$ & $\begin{array}{l}14 \text { of } 25 \text { ( } 56 \% \text { ) showed no NF2 expression; } 18 \text { of } 25 \text { (72\%) showed } \\
\text { losses at one or both loci tested. }\end{array}$ \\
\hline $\begin{array}{l}\text { Heterogeneity of mesothelioma cell lines as defined by altered } \\
\text { genomic structure and expression of the NF2 gene [252] }\end{array}$ & $\begin{array}{l}\text { Northern blot, RT-PCR and PCR. } \\
18 \text { HMM cell lines }\end{array}$ & $\begin{array}{l}\text { NF2 alterations were identified at a genomic level in } 7 \text { (39\%) cell lines } \\
\text { and were associated with a marked decrease in the concentration of the } \\
\text { NF2 transcript. }\end{array}$ \\
\hline $\begin{array}{l}\text { Establishment and characterization of four malignant pleural } \\
\text { mesothelioma cell lines from Japanese patients [248] }\end{array}$ & $\begin{array}{l}\text { PCR, SSCP analysis and Western Blot } \\
4 \text { HMM cell lines }\end{array}$ & A point mutation of NF2 was observed in 1 cell line. \\
\hline $\begin{array}{l}\text { Genomic profiling of malignant pleural mesothelioma with } \\
\text { array-based comparative genomic hybridization shows }\end{array}$ & $\begin{array}{l}\text { Genome-wide array-based CGH, RT-PCR } \\
9 \text { MPM cell lines and } 17 \text { MPM samples; }\end{array}$ & $\begin{array}{l}\text { Small deletions resulting in frameshift mutation were found in } 3(18 \%) \\
\text { MPM samples. }\end{array}$ \\
\hline
\end{tabular}


summarized in Table 2. Furthermore, recent studies have strengthened this data. A study has found that 38\% of MPM samples displayed NF2 mutation, and $29.4 \%$ displayed deletions, while no NF2 mutation was found in non-small cell lung cancer patients [97]. It has been shown that $38 \%$ of MM samples display chromosomal loss at 22q12 [82]; moreover, the NF2 was hypothesized to be an early molecular alteration due to loss of heterozygosity in a well-differentiated papillary mesothelioma of the peritoneum (WDPMP), a rare type of mesothelioma [98]. Not surprisingly, miRNA expression targeting NF2 has been reported in MM [99].

In order to better understand the role of NF2 in MM development, animal models have shed some light on the role of this gene. Altomare et al. [22] developed a NF2 ${ }^{(+/-)}$knockout mice and an environmental carcinogenesis model. The asbestos-exposed NF2 ${ }^{(+/-)}$mice exhibited an increase in tumor development, in comparison to the wild-type mice; in addition, it was observed biallelic inactivation in all nine asbestos-induced MM from NF2 ${ }^{(+/-)}$mice. Lastly, it was shown that tumors from $N F 2^{(+/-)}$mice frequently showed homozygous deletion of the $p 16^{I N K 4 a}, p 14^{A R F}$ and $p 15^{I N K 4 B}$, which is a similar feature of human MM. Following this line, Jongsma et al. [100], using a conditional knockout animal model, showed the importance of NF2, TP53 and $p 16^{I N K 4 a}$ and $p 14^{A R F}$ on the development of MM.

Taken altogether, these animal studies resembling molecular features of human MM are important to better understand the roles of these genes, and also to design better treatment approaches targeting relevant pathways.

\subsubsection{NF2 gene therapy}

The overexpression of NF2 by viral vectors has been shown in several other cancers with interesting results on the cell cycle control and proliferation [101-104]. In MM, the re-expression of NF2 led to significant inhibition on cellular proliferation and invasiveness [105], cell proliferation inhibition, $G_{1}$ phase arrest, reduction on cyclin D1 expression, inhibition of CDK4 activity, and dephosphorylation of pRb [106].

\section{3. $B A P-1$ and $M M$}

Genetic susceptibility has been related to the development of MM. In a study in Turkish villages with high incidence of MM, it was shown that MM was genetically transmitted likely in an autosomal dominant way [107]. Another study has found that family members genetically predisposed to MM, when raised outside the villages did not seem to develop MM; in addition, when high-risk MM family members married into families with no history of MM, MM appeared in the descendants [108]; however, the effects of genetic factors on MM have been questioned [109].

On the other hand, very recently more solid evidence has been reported. The BAP1 (BRCA1-associated protein 1) is a tumor suppressor gene located on chromosome 3p21 and encodes the BAP1, which is a deubiquitinating enzyme that seems to regulate deubiquitination during DNA damage response, and the cell cycle (Fig. 3). In recent times, it has been shown BAP1 germline mutations in two families with high incidence of MM, and thus characterizing the existence of a BAP1related cancer syndrome known by the presence of MM, uveal melanoma, [11,24,110], and possibly other types of cancer [111]. Furthermore, $B A P 1$ somatic mutations have been identified in $23 \%$ of sporadic mesothelioma [112]. Interestingly, the lack of BAP1 activity has been shown to be more specifically involved in the pathogenesis of epithelioid MM rather than non-epithelioid MM [113]. A recent clinical study has shown that indeed $20 \%$ of MPM tumors harbor BAP1 somatic mutations; however, no difference in survival was found when comparing with BAP1 mutation status [114]. On the other hand, conflicting data has been reported, in which high levels of BAP1 (non-mutated form) expression was related to shorter overall survival in MPM tissue samples [115].

The role of BAP1 in the development of MM and other cancers, as well as its mutations have been recently addressed [116]. Furthermore, germline mutation on BAP1 confers increased susceptibility for the development of MM and among other tumors [117], while somatic mutations have been shown to implicate transcriptional dysregulation in the pathogenesis of MPM. Taken altogether, genetics have been extensively implicated in the development and predisposition of MM, and in a near future the outcomes from these studies will help not only to better treat, but also to prevent more cases of MM, especially in those individuals more prone to its development.

\subsection{LATS2}

LATS (Large Tumor Suppressor) was first found as a tumor suppressor in Drosophila [118]. In humans the LATS1 and LATS2 have been identified, the latter one residing in a region (13q11-12), which frequently displays loss of heterozygosity in primary cancers $[119,120]$. The human LATS2 (Fig. 3) is a centrosomal protein, known to play an important role in the mitotic division [121], in mediating Hippo growth-inhibitory signaling [37], and to activate p53 [122]. The function of LATS in the cancer realm has been recently reviewed, and will not be further discussed here [123].

\subsubsection{LATS2 and MM}

Using CGH (Comparative genomic hybridization) analysis in $14 \mathrm{MM}$ cell lines, three MM cell lines displayed homozygous deletion at 13q12.11, which was confirmed by PCR analysis; moreover, in $20 \mathrm{MM}$ cell lines, 7 genetic mutations of LATS2 were found; in addition, 3 of 25 (12\%) primary tumors displayed genetic alterations that led to inactivation. In the same study, the transduction of LATS2 in MM cells carrying mutations in this gene led to MM cell proliferation suppression. Therefore, LATS2 seems to play an important role in cell proliferation and survival; however further studies are needed in order to confirm whether this gene is important in the development of MM [25].

\subsection{DNA methylation and MM}

In MM, DNA methylation studies have brought interesting results. It has been shown that methylation profile can discriminate between normal pleura from mesothelioma [124]. Likewise, another study has found a unique methylation profile in MM, which eventually could be used as diagnostic markers [125]. The analysis of the methylation status of nine genes in serum DNA of mesothelioma patients demonstrated interesting results on patient survival [126]. Several other studies analyzing patient outcome, diagnosis, as well as epigenetic therapy, were extensively revised by other authors $[15,127]$.

\subsection{MicroRNA and MM}

The miRNA expression is another important mechanism in the development of cancer due to its ability to control several biologic processes. Not surprisingly, it has been shown differences between the expression profile of miRNA in MM, in comparison to normal pleura; in addition, in each histopathological subtype of MM, specifically miRNA patterns have been found [99].

It has been shown that MM cell lines derived from patients with more aggressive cancer do not express mirR-31; moreover, the reintroduction of miR-31 led to suppression on cellular growth; thus showing a potential therapy for MM tumors that fail to express miR-31 [128]. Likewise, the miR-15/16 has been demonstrated to be downregulated in MPM cell lines in comparison to MET5-A. The restoration of miR-15/16 levels led to growth inhibition in MPM cell lines [129]. In addition, the relationship between miRNA expression, patient diagnosis and outcome has been extensively revised by other authors [15].

Therefore, miRNA have been proposed as diagnostic tool [130-132], as prognostic makers [163,164], and as treatment target option [129,133] for MM. 


\subsection{Other genes and $M M$}

The salvador gene (SAV), component of Hippo cascade (Fig. 3), was first discovered in a Drosophila [134], and it has been suggested to be a tumor suppressor gene in some cancers $[16,135]$. Recently, it was shown that SAV had a homozygous deletion at chromosome $14 \mathrm{q} 22$ in one $(5 \%)$ MM cell line; however the function of this gene has yet to be established in MM [25].

Furthermore, it has been found a homozygous deletion in the gene $\beta$-catenin (CTNNB1) (Fig. 3) in one (10\%) MM cell line [136]; in addition, it was shown that CTNNB1 is a positive growth-stimulating factor for many human cancers [137]; however its role in MM has not been fully addressed.

A recent study has suggested that the Hedgehog signaling pathway is active in MM cell lines [138]; in addition, it has been shown that 13 genes regulate this pathway in cancer; however only three of these genes (PTCH1, SMO and SUFU) were indeed mutated in 2 of $11 \mathrm{MM}$ cell lines [138]. Regarding MM patient tumors, only one patient (7.15\%) showed a mutation in SMO [139]. Recently, new genomes techniques have been applied showing new potential TSGs in MM [140]. Therefore, further studies are needed in order to confirm whether these genes are indeed important to MM tumorigenesis.

The circadian rhythms are generated by several genes and proteins, which ultimately regulate several biologic processes, such as: sleep regulation, body temperature, hormones, immune system response, and others [141]. It has been shown a correlation between a disruption of circadian rhythms and incidence of breast cancer [142]. Likewise, it has been shown that chronomodulated anticancer regimes in male patients display an increase on survival rates, in comparison to traditional chemotherapy [143]. In MM, more evidence has emerged showing that the clock genes PER (period), CRY (cryptochrome) BMAL1 (aryl hydrocarbon receptor nuclear translocator-like) (Fig. 3) were expressed in favor of tumor growth [144]. More recently, a therapeutic target approach inhibiting BMAL1 expression has been proposed showing a reduction on tumor growth in MM cell lines expressing high levels of BMAL1 [145].

\section{Important pathways in MM}

\subsection{Receptors tyrosine kinases}

The RTKs regulate cell cycle control and proliferation and are frequently activated in MM [146], leading to upregulation of RAS/RAF/ MEK/MAPK and PI3K pathway (Fig. 4) [147].

The EGFR is often overexpressed in MM [148]. EGFR has been detected in 44\% of MPM [28], and its expression has been correlated with long term survival [149]; however conflicting data has also been published [150]. Despite that MM displays high expression of EGFR, gefitinib [151] and Erlotinib [152], both EGFR inhibitors, were not active in MM in phase 2 clinical trials.

The VEGF and their specific transmembrane receptors (VEGFR-1 and VEGFR-2) are a potent inducers of angiogenesis, and are expressed in MM $[30,153,154]$, being associated with a reduction on patient survival $[30,155]$; however, a study did not find a correlation between VEGF expression and an improvement on patient survival [156]. Likewise, it has been shown that SV40 induces VEGF expression in MM cell lines, which enhances their proliferation. VEGF may not only stimulate the tumor angiogenesis, but also tumor growth [157]. According to Lee et al. [27], prolonged survival rates in animals were observed in MPM cell lines treated with the antibody Bevacizumad in combination with

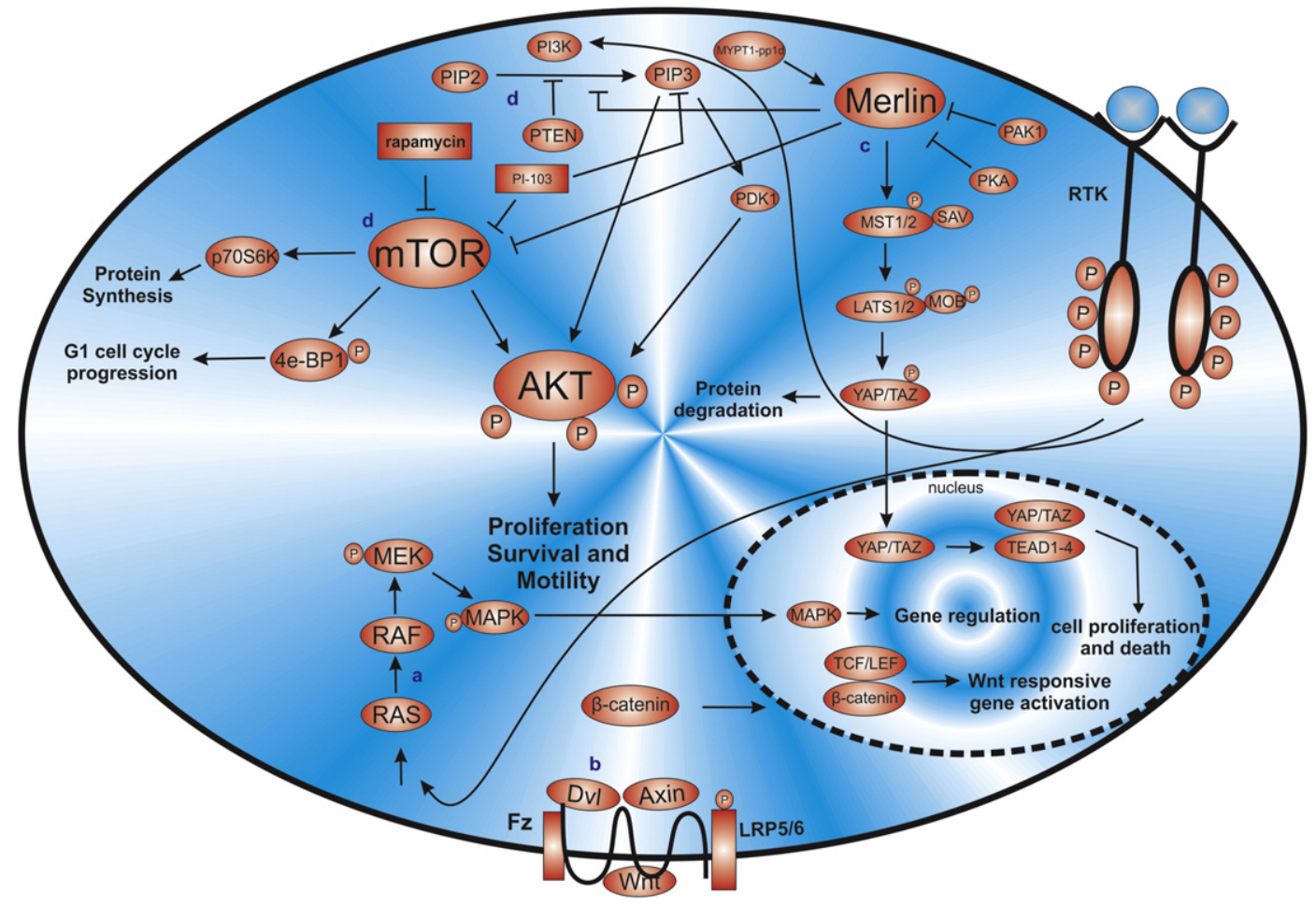

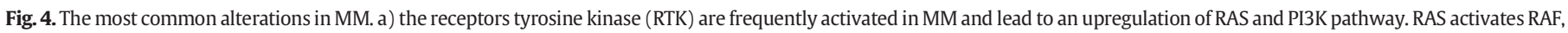

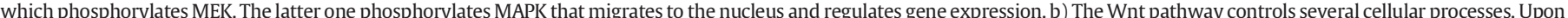

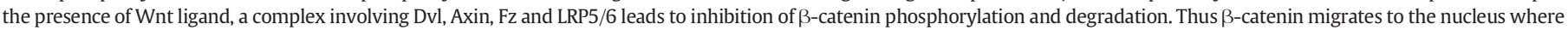

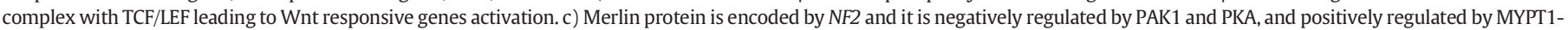

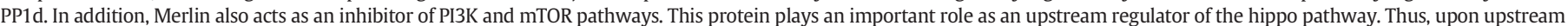

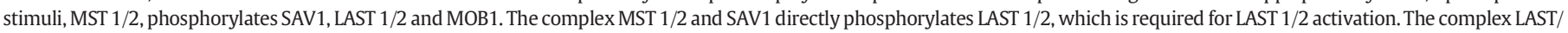

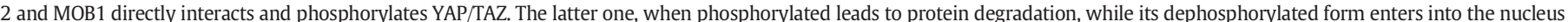

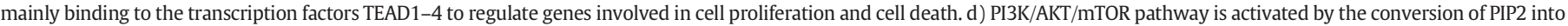

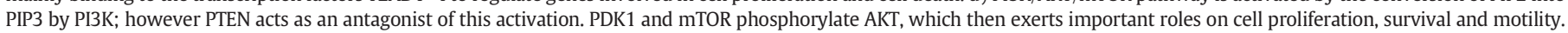
mTOR leads to protein synthesis and G1 cell cycle progression and it is inhibited by rapamycin and by PI-103. 
Pemetrexed. Regarding anti-VEGF therapy, erlotinib and bevacizumab in combination with chemotherapy were also evaluated in MM [158].

Insulin growth factor (IGF) and Insulin growth factor receptors (IGFR) are expressed by MM [159], and by normal mesothelial cell lines [27]; however, dysregulation of IGF pathway may lead to malignant transformation [27]. Stimulation by IGF-I resulted in enhanced activation of IGFR leading to cell proliferation [160]. A study has found that IGF-I was overexpressed in 11 MPM cell lines and in 4 primary tumors [161]; moreover, a recent study has demonstrated an interesting finding. The authors assayed the expression of IGF-I receptors (IGF-IR), and found considerable variability among several MM tumor samples and cell lines. Furthermore, in this same study, the IGF-I surface receptors were quantified by flow cytometry, confirming the previous results mentioned, and more remarkably, the anti-tumor efficacy with cixutumumab and inhibition of IGF-IR downstream signaling were highly correlated with IGF-IR sites per cell [162].

Lastly, Hepatocyte Growth Factor Receptor (MET) is a protooncogene that is commonly expressed in MM and it is not mutated $[165,167]$. Inhibition of MET has been proposed as therapeutic strategy option for MM [166,168]. Combined inhibition of MET and EGFR led to strong inhibition on cell proliferation and invasion of MPM cell lines [167].

\subsection{Ras/Raf/MEK/MAPK pathway}

The RAS/RAF/MEK/MAPK signaling pathway comprises cell surface receptors, transcription factors, which regulates gene expression. This pathway is one of the most dysregulated in cancer and regulates critical cellular function, such as: proliferation, growth and senescence. The RAS/RAF/MEK/MAPK pathway influences the regulation of apoptosis through interaction with BAD, Caspase 9 and BCL-2 [169].

RAS is a single GTPase molecule and it has tree isoforms (H-Ras, K-Ras and N-Ras). In its "off" state, RAS is bound to GDP; however, upon stimuli, RAS binds to GTP ("on" state) [170]. In its "on" state, RAS, combines with $\mathrm{RAF}$ and mobilizes the inactive protein from the cytoplasm recruiting the RAF kinases (ARAF, BRAF and CRAF) to the plasma membrane [171]. Onto the cell membrane, RAS activates the RAF, which then acts as a MAP kinase kinase kinase (MAPKKK) activating MEK1 and MEK2. The latter two, catalyze the activation and translocation into the nucleus of MAPK1 and MAPK2. Thus, once activated, MAPK1 and MAPK2 kinases phosphorylate several genes involved in several important cellular responses (Fig. 4) [171,172]. Also, it is known that RAS can activate other downstream pathways, such as: PI3K, RAC and RHO [171].

In cancer, point mutation of the RAS family gene comprises at about $30 \%$ of all human cancer [171]. The gene BRAF that encodes the BRAF is also frequently mutated in human cancer [173]. Therefore, this pathway is indeed important to the development of cancer, and several inhibitors have been tested or are under clinical trial, which were extensively revised by Santarpia et al. [171].

\subsubsection{Ras/Raf/MEK/MAPK pathway in MM}

It has been shown in MM that the expression of phosphorylated MAPK1/2 was increased in comparison to normal lung tissue [174]; however, it has also been shown that MAPK activation was not able to differentiate between benign and MM cells [175].

In an animal study, it was shown prolonged MAPK1/2 activation after exposure to asbestos, in comparison to animals exposed to similar and nonpathogenic particles [176]. Interestingly, MAPK1/2 phosphorylation also occurs in distal bronchioles in a murine model of fibrogenesis [177]. Recently, an in vitro study showed that MAPK2 is critical to transformation and homeostasis of epitheliod MM; thus showing different roles between MAPK1 and MAPK2 in epitheliod MM, at least in vitro studies [178].

\subsection{PI3K/AKT/mTOR pathway}

The phosphatidylinositol 3-kinase (PI3K) pathway regulates several cellular processes, such as survival, metabolism, proliferation, vesicle trafficking, apoptosis, growth and cell migration, and among other functions in specific cellular contexts [179].

Phosphoinositide 3-kinase is part of a family of intracellular lipid kinases that phosphorylate the 3'-hydroxyl group of phosphoinositides and phosphatidylinositols. One of the products of this reaction is the PIP3 (phosphatidylinositol-3,4,5-triphosphate), which is a second messenger lipid [180] essential for the translocation of AKT to the plasma membrane, where it is phosphorylated, and activated by phosphoinositide-dependent kinase 1 (PDK1). The phosphorylated AKT (p-AKT) conveys downstream signals promoting cellular proliferation and survival over apoptosis (Fig. 4) [22].

According to the structure, substrate specificity and lipid products, the PI3Ks are subdivided into 3 categories (classes I, II and III). Class I is subdivided into IA and IB. The first class is activated by tyrosine kinase receptors, G-protein coupled receptors and oncogenes, and it has been widely implicated in cancer. This class is composed of heterodimers, comprising regulatory $\mathrm{p} 85$ and catalytic $\mathrm{p} 110$ subunits. The class IB members consist of a p101-regulatory subunit and are activated by $G$ protein-coupled receptors [180]. The classes II and III use phosphatidylinositol (PI) as a substrate to generate PIP3 [181].

The PIK3CA gene encodes the catalytic subunit $\mathrm{p} 110 \alpha$, which has been shown to increase the activity of this pathway [180]. This subunit phosphorylates the phosphatidylinositol biphosphate (PIP2) into PIP3 [182]. This second messenger is essential to translocate the serine/ threonine kinase AKT (also known as PKB) onto the plasma membrane [26,183]. AKT activation regulates along with PI3K, a large number of cellular processes, including cell proliferation, survival and motility [184]. When PIP3 binds to AKT, the recruitment occurs onto the membrane, which is followed by phosphorylation by the mammalian target of rapamycin (mTOR) [185].

The mTOR pathway has an important role in the energy balance of mammalian cell growth and size, and therefore, it is a relevant therapeutic target for dysregulated cellular growth, including cancer [186]. Activation of mTOR leads to the phosphorylation of eukaryotic initiation factor 4E (eIF4E)-binding protein-1 (4E-BP1), thereby dissociating $4 \mathrm{E}-\mathrm{BP} 1$ from the mRNA cap binding protein eIF4E to promote protein synthesis [187]. Also, mTOR regulates the activity of the ribosomal protein $\mathrm{S} 6$ kinase ( $\mathrm{p} 70 \mathrm{S6K}$ ), that is required for cell growth and $\mathrm{G}_{1}$ cell cycle progression [188].

\subsubsection{PI3K/AKT/mTOR pathway and MM}

Alterations on the PI3K/AKT/mTOR are associated with more aggressive diseases, such as cancer. This pathway is a major survival pathway in several tumors, and it has been shown to be active in mesothelioma cell lines [189]. When the signaling cascade is dysregulated, there is a disrupted translation of mRNAs that are involved in cellular processes, such as cell cycle progression, growth stimulation, cell survival, invasion and interaction with extracellular matrix [190], and apoptotic resistance [191].

AKT has a central role in a signaling pathway of which many of its components have been linked to tumorigenesis. AKT can be activated by a variety of mechanisms: loss or downregulation of PTEN [192], activation of PI3K in autocrine or paracrine stimulation of the RTK [192,193]; mutation of the PI3K catalytic or regulatory subunits [194], and/or Ras activation [195].

There are 3 isoforms of AKT: AKT-1, 2 and 3. Gene amplification of AKT-1 and AKT-2 are infrequent, but it has been reported in some types of cancers [196-198]. In MM, there is an increased activity of this kinase, which can be a pharmacological target used in order to increase the effectiveness of chemotherapy [22]. The lack of PTEN expression leads to elevated levels of p-AKT [199].

mTOR mediates survival in MM, thus Wilson et al. [23] reported that rapamycin (an mTOR inhibitor) was able to reduce the apoptosis resistance in more than $50 \%$ of MM tumors samples. Kim et al. [200] demonstrated a reduction on cell resistance to apoptosis due to inhibition of mTOR, by rapamycin. 
One of the components of this pathway is the lipid phosphatase protein, PTEN, that dephosphorylates PIP3 into PIP2, thus acting as a central negative regulator of PI3K [181], by inhibiting AKT activation. PTEN also regulates chemotaxis and cell motility, both mechanisms that promote tumor invasion $[84,85]$. Few MM studies have shown PTEN homozygous deletion [22,26] or alteration on the expression [201,202], and their relationship with the suppression of cellular growth by AKT blockade. Therefore, these findings suggest that the protein phosphatase activity of PTEN may contribute to its tumor suppressor function in a subset of MMs.

The activated $\mathrm{p} 110 \alpha$ catalytic subunit, which is encoded by the PIK3CA is a frequently mutated gene in cancer. Mutations in the p $110 \alpha$ have been identified in about $12 \%$ of all human cancers [203]. Thus, there are three "hot spots" mutations identified on PIK3CA: E542K, E545K (helical domain) and H1047R (kinase domain) [204]. Several studies have linked the role of PTEN in negatively regulating the expression of AKT, and today, it is well accepted that the PI3K-AKT pathway is overexpressed in MM [22,26,201]. Furthermore, it has been shown that the overexpression of PTEN by transfecting cells with an adenoviral vector increased apoptosis in mesothelioma cell lines, due to AKT hypophosphorylation [201].

A study has found a reduction on mRNA levels of PIK3CA in patients with malignant peritoneal mesothelioma, which was correlated with an improvement on survival rate [205]. In another study, Suzuki et al. [26] demonstrated a dysregulation of PI3K-AKT pathway in MM cell lines. Furthermore, it has been shown AKT activation, and low or no expression of PTEN in MM cells lines [200].

As described above, several survival or anti-apoptotic mechanisms have been identified in MM, and they have been shown to influence survival and resistance to chemotherapy; however, it is not fully understood the role of mutations and mechanisms on the activity of AKT and $\mathrm{PI} 3 \mathrm{~K}$, and their relationship with the development of MM.

\subsubsection{Therapeutic targets}

MM is a very aggressive tumor, but advances in the treatment of this disease have emerged. The tumor is highly resistant to chemotherapy, mainly due to resistance to apoptosis [206]. MM remains an unusual tumor, and thus it is difficult to study it in large clinical trials. Some animal and cellular models have been proposed for the study of this cancer.

$\mathrm{PI} 3 \mathrm{~K} / \mathrm{AKT} / \mathrm{mTOR}$ pathway is involved in MM carcinogenesis, and the elucidation of the downstream targets that dictate cellular response to this signaling pathway may have important implications for the development of MM treatment therapies. The treatment with PI3K inhibitors has been shown to inhibit the growth of many types of cancer cells by inducing cell cycle arrest and apoptosis [207,208].

Rapamycin treatment is able to inhibit activity of both mTOR and AKT, suggesting that it may be an effective therapeutic blockade of PI3K signaling [181]. It has been found that inhibitors of the PI3K and mTOR pathways were successful in enhancing apoptosis in human mesothelioma spheroids [200,209].

There is also a proposal to inhibit several targets of the PI3K pathway: Knight and Shokat [210] have developed a dual inhibitor of $\mathrm{p} 110 \alpha$ and mTOR called PI-103. It has been effective in blocking proliferation of Glioma and other tumor cells in vitro. Furthermore, inhibition of other targets, including AKT and PDK1 has also been investigated [211]. Regarding inhibiting AKT activity, in addition to Rapamycin, the triciribine has been used to inhibit the phosphorylation of all 3 AKT isoforms, and tumor growth of cells overexpressing AKT in mouse xenograft models [212]. Several inhibitors of PI3K/AKTMTOR have been developed. However, these inhibitors may have limited effectiveness in human cancers.

\subsection{The BCL-family and MM}

In general, the majority of cancers, including MM [206], show resistance to apoptosis [213]. The BCL-2 family of proteins is important in controlling this process. This family is subdivided into pro- and antiapoptotic members. All these proteins have at least one BCL-2 Homology (BH) domain. The BCL-2, BCL-XL, BCL-W and MCL-1 are among the antiapoptotic members that inhibit cells from undergoing programmed death. On the other hand, the pro-apoptotic proteins members are BAD, BID and BIM [214], which induce permeability of the mitochondrial membrane, resulting in caspase activation [20]. There are also the multidomain pro-apoptotic proteins, such as BAX and BAK, which contain BH1-BH3 domains [20].

MM cell lines rarely express BCL-2, but often express BCL-XL $[35,36]$, and a normal contingent of pro-apoptotic $B C L-2$ family genes [35,215]. Due to great resistance to apoptosis, low BCL-2/BAX ratio has been reported in mesothelioma cells, which implicates into a mechanism other than BCL-2 in regulating apoptosis $[4,215]$.

Few studies have shown modulation of BAX, BAD, BIM, BAK and MCL-1 in MM. Yuan et al. [225] observed that MCL-1 was the major survival player in regulating MG132-induced apoptosis in MPM cell lines. Moreover, BAX and BAK require a subset of pro-apoptotic BCL-2 family proteins for activation, two of them (BID and BIM), induce oligomerization and activation of BAX. It has been reported in MM, the loss of expression of BID (37\%) and BIM (18\%) [20]. Lastly, in a study using immunohistochemical analysis, it was found that $100 \%$ of a series of 35 mesothelioma samples expressed BAX [35].

\subsubsection{Therapeutic targets}

Few studies have shown therapeutic strategies that target activation or blockade of the BCL-2 family members. Following this line, Zhang et al. [216] and Raisova et al. [217] have shown that the ratio BAX/ $\mathrm{BCL}-2$ or $\mathrm{BAX} / \mathrm{BCL}-\mathrm{XL}$ in tumor cells is an important determinant of susceptibility to apoptosis, with more sensitive cells having higher BAX/BCL-2 or BAX/BCL-XL ratio.

The BCL-XL/BCL-2 inhibitors have been developed to disrupt the balance between pro-apoptotic and anti-apoptotic stimuli [218]. Several small-molecular ligands for BCL-2 and/or BCL-XL have also been identified [219].

Moreover, a study has demonstrated that pharmacological inhibition of BCL-XL expression by exposure to a histone deacetylase inhibitor, sodium butyrate (NaB), led to apoptotic cell death in MM. A recombinant adenoviral vector expressing pro-apoptotic Bax, has been shown to be effective in inducing apoptosis in human MM [220]. An antisense oligonucleotide therapy directed at Bcl-xl mRNA was used in vitro to downregulate the $B C L-X L$ expression, and resulted in apoptosis and viability decrease in human mesothelioma cell lines [221]. Another therapy that has shown good outcomes was the combination of antisense oligonucleotide in combination with cisplatin, which reduced growth of established tumor xenografts in mice [222].

Furthermore, Varin et al. [223] showed that the simultaneous inhibition of BCL-XL and MCL-1 by small interfering RNA (siRNA) was able to induce massive cell death in the absence of chemotherapy, and was enough to avoid treatment resistance in MSTO- $211 \mathrm{H}$, a MM cell line; thus showing a strong molecular basis for the clinical evaluation of therapies targeting both BCL-XL and MCL-1, alone or in combination with traditional chemotherapy in the treatment of MM.

The JY-1-106 protein induces cancer cell death regardless of MCL-1 expression levels through the intrinsic apoptosis pathway, sensitizes tumor cells to chemotherapeutic agents and to metabolic stress; in addition, it induces apoptosis by disrupting BCL-XL and MCL-1 protein-protein interactions with BAK [224]. Another study has demonstrated that 2-methoxy antimycin A3 is able to induce apoptotic cell death without altering BCL-2 family protein expression [218].

Given the findings, we believe that more studies are needed to elucidate and/or discover possible therapeutic strategies to inhibit or activate the BCL-2 family members in MM, mainly focusing on the mechanisms that induce apoptosis. 


\subsection{The Merlin protein}

The NF2 encodes the protein Merlin. There are at least 10 known isoforms of Merlin protein, and the isoforms I and II are the most common. Merlin structural conformation is important to its activation. The "close" conformation is required for tumor suppressor activity, while the "open" conformation leads to loss of the tumor suppressor activity. Moreover, Merlin is phosphorylated by p21-activated kinase 1 (PAK1) or cAMP-dependent kinase A (PKA) on serine 518, and thus leading to its inactive form; on the other hand, the myosin phosphatase (MYPT1PP1d) dephosphorylates Merlin (Fig. 4), which leads to its activation [226,227].

Furthermore, it has been shown that Merlin regulates cytoskeleton remodeling, cell motility, cell proliferation, morphology and motility [228]. Merlin also negatively regulates several signaling pathways, such as PI3K [229], mTOR [230], (EGFR) [231], and cyclin D1 expression [106]. In MM, Merlin phosphorylation has been reported, resulting in its inactivation [232]. Lastly, Merlin plays a crucial role as an upstream regulator of the hippo pathway [25].

\subsubsection{The hippo pathway}

Initially first identified in Drosophila, the hippo pathway controls cell proliferation, growth, differentiation and death [37]. The core components of this pathway are MST1/2, SAV, LATS $1 / 2$, MOB and YAP/TAZ. A brief summary of the activation of this pathway is further described. Upon upstream stimuli, MST 1/2, phosphorylates SAV1, LATS $1 / 2$ and MOB1. The complex MST 1/2 and SAV1 directly phosphorylates LATS $1 / 2$, which is required for LATS $1 / 2$ activation. The complex LATS $/ 2$ and MOB1 directly interacts and phosphorylates YAP/TAZ. The latter one, when phosphorylated leads to protein degradation, while its dephosphorylated form enters into the nucleus mainly binding to the transcription factors TEAD1-4 to regulate genes involved in cell proliferation and cell death (Fig. 4) [37,228].

\subsubsection{Merlin-hippo pathway and MM}

The hippo pathway has been implicated in the development of MM. Loss of LATS2 has been reported in MM (see LATS2 and MM section). $Y A P$, an oncogene candidate, had its expression detected in more than $70 \%$ of MM tissues [25]. The $S A V$, which is a component of the hippo pathway, has been found altered in one MM cell line [see Other genes and MM section]. Furthermore, Merlin has been shown to inhibit the YAP nuclear function, the main downstream effector of Hippo pathway, through phosphorylation at serine 127 [233]. Another study has found that YAP-knockdown inhibits cell motility, proliferation, invasion and anchorage-independent growth in MM cell lines; in addition, it was found in MM cell lines with constitutive YAP-activation, that YAP activation promotes cell cycle progression, which results in more aggressive MM cells [38]. Lastly, the hippo pathway has been shown to interact with TGF- $\beta$ pathway in regulating the connective tissue growth factor, which is associated with abundant extracellular matrix formation in MM tissues [39].

Taken altogether, the Merlin-hippo pathway plays an important role in driving MM tumorigenesis; however further studies are needed in order to better understand the role of LATS and SAV as tumor suppressor genes in regulating this pathway in MM, as well as to better understand the downstream consequences evoked by mutations on these genes.

\subsection{Wnt pathway}

Wnt signaling pathway plays a fundamental role in the determination of cell fate, proliferation, polarity, and cell death during embryonic development. This pathway was discovered more than 30 years ago [40], and it has been implicated in the development of human diseases [reviewed in 234], and in cancer [reviewed in 235].

Activation of Wnt signaling that alters transcription is called canonical, on the other hand, non-transcriptional Wnt signaling is called noncanonical. $\beta$-catenin is the essential downstream transcriptional effector of this pathway. Thus, in the absence of Wnt ligand, cytoplasmic $\beta$-catenin is degraded by the action of the Axin complex, which is composed of the scaffolding protein Axin, the tumor suppressor adenomatous polyposis coli gene product (APC), casein kinase 1 (CK1), and glycogen synthase kinase 3 (GSK3). The latter two phosphorylate $\beta$-catenin leading to proteosomal degradation, which inhibits $\beta$-catenin transcriptional activity (Fig. 4) [40].

On the other hand, upon the presence of Wnt ligand, Wnt/B-catenin canonical pathway is activated due to a complex formation between seven-pass transmembrane Frizzled (Fz) receptor and low-density lipoprotein receptor-related protein 5 or 6 (LRP6/LRP5). This complex together with the scaffolding protein Dishevelled (Dvl), leads to LRP6 phosphorylation, activation and recruitment of Axin complex to the receptors, which leads to inhibition of $\beta$-catenin phosphorylation and degradation by Axin complex (Fig. 4). Thus $\beta$-catenin migrates to the nucleus, where it forms a complex with TCF/LEF leading to Wntresponsive gene activation [236].

\subsubsection{Wnt pathway and MM}

The Wnt signaling pathway has been reported in MM, through Dvl overexpression [41]. It has been shown that secreted frizzled-related proteins (sFRPs) antagonize, and act as a negative regulator of Wnt signaling pathway; in addition, it has been shown downregulation of SFRPS in approximately $85 \%$ of primary MM tumors due to promoter methylation. The re-expression of $s F R P$ in MPM cell lines lacking sFRPS expression resulted in apoptosis and growth suppression [237].

The protein inhibitory factor-1 (WIF-1) antagonizes Wnt signaling, and it has been shown to be downregulated in MM cell lines, and in primary tumors due to promoter hypermethylation [238]. Promoter methylation of WIF-1 was observed in $73.9 \%$ of mesothelioma tissues and in all 8 MM cell lines. SFRP1, 2 and 4 promoter methylation was observed in 21 of 37 (56.8\%), 26 of 42 (61.9\%) and 17 of 36 (47.2\%) MM tissues, respectively [239]. Furthermore, nuclear accumulation of $\beta$-catenin has been reported in MM [240]; however conflicting data has also been published regarding nuclear accumulation of $\beta$-catenin $[239,241]$.

A recent study has shown altered expression levels of a number of Wnt/Fzd signaling molecules in MM, and it has been proposed that the modulation of Wnt signaling in MM may sensitize it to cytotoxic drugs [242]. Likewise, it has been shown a lower overall survival rate of patients expressing tumors with high levels of Wnt2B, in comparison to tumors expressing low expression levels of Wnt2B [243]. Inhibition of Wnt2 by siRNA or by monoclonal antibody induced cell death in MPM cell lines [244], another study has found similar findings [245]. Lastly, $\beta$-catenin staining has been proposed as a marker in the diagnosis of mesothelial lesions [246].

Therefore, Wnt pathway has an important role on the development of MM and it is a good candidate for new therapeutic approaches targeting Wnt pathway inhibition.

\section{Conclusions}

As we have seen, once the diagnosis is made, most of the MM patients are left with a short life expectancy of less than a year; in addition, this cancer can take up to 40 years to manifest. Thus, this discrepancy between the start of the carcinogenic process and the diagnosis could be used in favor of the patient, since unlike other cancers, MM takes a long time to manifest. Moreover, the risk factors are of great importance in the development of this cancer, such as erionite, asbestos and SV40; however, more studies are needed in order to better comprehend how these players influence the development of MM, as well as the levels of exposure that are indeed dangerous for the population. Fortunately, the majority of the population is not exposed to such risk factors, something that extensively reduces the likelihood of developing MM. 
However, early diagnostics, especially in the population at risk, such as people directly or indirectly expoused to asbestos, erionite or SV40, should be undertaken periodically. Yet, as we have seen, a lot of research is ongoing in order to create good and trustworthy diagnostic markers, which would eventually help many people. This fact in association with an ever-increasing knowledge on the biochemical and genomic pathways to drive the tumorigenesis of MM, gives us valuable clues, which would ultimately result in the production of more specific molecules and drugs, which would be used to fight against the process of malignant transformation, establishment and metastasis. Taken altogether, our work shows that several genes and pathways are involved in the development of MM; however, more studies are needed in order to better understand, prevent, diagnose, and treat this very aggressive cancer.

\section{Acknowledgements}

The first author of this paper thanks CAPES (Coordenação de Aperfeiçoamento de Pessoal de Nível Superior) and the Brazilian government through the Science without Borders program for granting a one year full scholarship at the University of Montana, USA; Dr. Mark Pershouse, associate professor of the Department of Biomedical and Pharmaceutical Science at the University of Montana, USA, for his teachings, lessons and mentoring. All the authors of this paper thank Pablo Henrique Oliveira e Silva for extensively revising this manuscript; Izabella Imperatriz Moreira Dalboni de Souza for editing the figures present in this paper; CNPQ and Fundação de Amparo à Pesquisa do estado de Minas Gerais (FAPEMIG, grants APQ 2112-10 and APQ 00793-13) for the financial support given to our Laboratory at the Federal University of Ouro Preto (UFOP).

\section{References}

[1] C. Tan, T. Treasure, Mesothelioma: time to take stock, J. R. Soc. Med. 98 (2005) $455-458$.

[2] M.R. Becklake, E. Bagatin, J.A. Neder, Asbestos-related diseases of the lungs and pleura: uses, trends and management over the last century, Int. J. Tuberc. Lung Dis. 11 (2007) 356-369.

[3] F.E. Mott, Mesothelioma: a review, Ochsner J. 12 (2012) 70-79.

[4] D.A. Fennell, Genetics and molecular biology of mesothelioma, Malignant Mesothelioma, vol. 189, Springer, Berlin Heidelberg, 2012, pp. 149-167.

[5] H. Yang, J. Testa, M. Carbone, Mesothelioma epidemiology, carcinogenesis, and pathogenesis, Curr. Treat. Options in Oncol. 9 (2008) 147-157.

[6] J.P. van Meerbeeck, R. Gaafar, C. Manegold, R.J. Van Klaveren, E.A. Van Marck, M. Vincent, C. Legrand, A. Bottomley, C. Debruyne, G. Giaccone, Randomized phase III study of cisplatin with or without raltitrexed in patients with malignant pleural mesothelioma: an intergroup study of the European Organisation for Research and Treatment of Cancer Lung Cancer Group and the National Cancer Institute of Canada, J. Clin. Oncol. 23 (2005) 6881-6889.

[7] J.C. Wagner, C.A. Sleggs, P. Marchand, Diffuse pleural mesothelioma and asbestos exposure in the North Western Cape Province, Br. J. Ind. Med. 17 (1960) 260-271.

[8] ATSDR, Public Health Statement for Asbestos, 2001.

[9] J.J. Manfredi, J. Dong, W.J. Liu, L. Resnick-Silverman, R. Oiao, P. Chahinian, M. Saric, A.R. Gibbs, J.I. Phillips, J. Murray, C.W. Axten, R.P. Nolan, S.A. Aaronson, Evidence against a role for SV40 in human mesothelioma, Cancer Res. 65 (2005) 2602-2609.

[10] P. Carthew, R. Hill, R. Edwards, P. Lee, Intrapleural administration of fibres induces mesothelioma in rats in the same relative order of hazard as occurs in man after exposure, Hum. Exp. Toxicol. 11 (1992) 530-534.

[11] M. Cheung, J. Talarchek, K. Schindeler, E. Saraiva, L.S. Penney, M. Ludman, J.R. Testa, Further evidence for germline BAP1 mutations predisposing to melanoma and malignant mesothelioma, Cancer Genet. 206 (2013) 206-210.

[12] C.T. Yang, L. You, C.C. Yeh, J.W.C. Chang, F. Zhang, F. McCormick, D.M. Jablons, Adenovirus-mediated p14ARF gene transfer in human mesothelioma cells, J. Natl. Cancer Inst. 92 (2000) 636-641.

[13] S. Xio, D. Li, J. Vijg, D.J. Sugarbaker, J.M. Corson, J.A. Fletcher, Codeletion of p15 and p16 in primary malignant mesothelioma, Oncogene 11 (1995) 511-515.

[14] M. Ladanyi, Implications of P16/CDKN2A deletion in pleural mesotheliomas, Lung Cancer 49 (2005) S95-S98(Amsterdam, Netherlands).

[15] D. Jean, J. Daubriac, F.o. Le Pimpec-Barthes, F.o. Galateau-Salle, M.C. Jaurand, Molecular changes in mesothelioma with an impact on prognosis and treatment, Arch. Pathol. Lab. Med. 136 (2012) 277-293.

[16] K.P. Lee, J.H. Lee, T.S. Kim, T.H. Kim, H.D. Park, J.S. Byun, M.C. Kim, W.I. Jeong, D.F Calvisi, J.M. Kim, D.S. Lim, The Hippo-Salvador pathway restrains hepatic oval cell proliferation, liver size, and liver tumorigenesis, Proc. Natl. Acad. Sci. 107 (2010) 8248-8253.
[17] C. Frezza, C.P. Martins, From tumor prevention to therapy: empowering p53 to fight back, Drug Resist. Updat. 15 (2012) 258-267.

[18] Y. Sekido, Genomic abnormalities and signal transduction dysregulation in malignant mesothelioma cells, Cancer Sci. 101 (2009) 1-6.

[19] A.A. Bahnassy, A.-R.N. Zekri, A.A. Abou-Bakr, M.M. El-Deftar, A. El-Bastawisy, M.A. Sakr, G.M. El-sherif, R.M. Gaafar, Aberrant expression of cell cycle regulatory genes predicts overall and disease free survival in malignant pleural mesothelioma patients, Exp. Mol. Pathol. 93 (2012) 154-161.

[20] S.L. O'Kane, R.J. Pound, A. Campbell, N. Chaudhuri, M.J. Lind, L. Cawkwell, Expression of bcl-2 family members in malignant pleural mesothelioma, Acta Oncol. 45 (2006) 449-453.

[21] T. Maehama, J.E. Dixon, The tumor suppressor, PTEN/MMAC1, dephosphorylates the lipid second messenger, phosphatidylinositol 3,4,5-trisphosphate, J. Biol. Chem. 273 (1998) 13375-13378.

22] D.A. Altomare, H. You, G.H. Xiao, M.E. Ramos-Nino, K.L. Skele, A. De Rienzo, S.C. Jhanwar, B.T. Mossman, A.B. Kane, J.R. Testa, Human and mouse mesotheliomas exhibit elevated AKT/PKB activity, which can be targeted pharmacologically to inhibit tumor cell growth, Oncogene 24 (2005) 6080-6089.

[23] S.M. Wilson, D. Barbone, T.-M. Yang, D.M. Jablons, R. Bueno, D.J. Sugarbaker, S.L. Nishimura, G.J. Gordon, V.C. Broaddus, mTOR mediates survival signals in malignant mesothelioma grown as tumor fragment spheroids, Am. J. Respir. Cell Mol. Biol. 39 (2008) 576-583.

[24] M. Carbone, L. Ferris, F. Baumann, A. Napolitano, C. Lum, E. Flores, G. Gaudino, A. Powers, P. Bryant-Greenwood, T. Krausz, E. Hyjek, R. Tate, J. Friedberg, T. Weigel, H. Pass, H. Yang, BAP1 cancer syndrome: malignant mesothelioma, uveal and cutaneous melanoma, and MBAITs. J Transl Med 10 (2012) 179.

[25] H. Murakami, T. Mizuno, T. Taniguchi, M. Fujii, F. Ishiguro, T. Fukui, S. Akatsuka, Y. Horio, T. Hida, Y. Kondo, S. Toyokuni, H. Osada, Y. Sekido, LATS2 is a tumor suppressor gene of malignant mesothelioma, Cancer Res. 71 (2011) 873-883.

[26] Y. Suzuki, H. Murakami, K. Kawaguchi, T. Tanigushi, M. Fujii, K. Shinjo, Y. Kondo, H. Osada, K. Shimokata, Y. Horio, Y. Hasegawa, T. Hida, Y. Sekido, Activation of the PI3K-AKT pathway in human malignant mesothelioma cells, Mol. Med. Rep. 2 (2009) 181-188.

[27] A.Y. Lee, D.J. Raz, B. He, D.M. Jablons, Update on the molecular biology of malignant mesothelioma, Cancer 109 (2007) 1454-1461.

[28] J.G. Edwards, D.E.B. Swinson, J.L. Jones, D.A. Waller, K.J. O'Byrne, EGFR expression: associations with outcome and clinicopathological variables in malignant pleural mesothelioma, Lung Cancer 54 (2006) 399-407(Amsterdam, Netherlands).

[29] D. Hanahan, J. Folkman, Patterns and emerging mechanisms of the angiogenic switch during tumorigenesis, Cell 86 (1996) 353-364.

[30] L. Strizzi, A. Catalano, G. Vianale, S. Orecchia, A. Casalini, G. Tassi, R. Puntoni, L. Mutti, A. Procopio, Vascular endothelial growth factor is an autocrine growth factor in human malignant mesothelioma, J. Pathol. 193 (2001) 468-475.

[31] H.L. Kindler, Moving beyond chemotherapy: novel cytostatic agents for malignant mesothelioma, Lung Cancer 45 (2004) S125-S127(Amsterdam, Netherlands).

[32] R.A. Kratzke, G.A. Otterson, C.E. Lincoln, S. Ewing, H. Oie, J. Geradts, F.J. Kaye, Immunohistochemical analysis of the p16INK4 cyclin-dependent kinase inhibitor in malignant mesothelioma, J. Natl. Cancer Inst. 87 (1995) 1870-1875.

[33] S.W. Lowe, C.J. Sherr, Tumor suppression by Ink4a-Arf: progress and puzzles, Curr. Opin. Genet. Dev. 13 (2003) 77-83.

[34] K. Segers, M. Ramael, S.K. Singh, E. Marck, J. Weyler, J. Meerbeeck, P. Vermeire, Immunoreactivity for bcl-2 protein in malignant mesothelioma and nonneoplastic mesothelium, Virchows Arch. 424 (1994) 631-634.

[35] Y. Soini, V. Kinnula, R. Kaarteenaho-Wiik, E. Kurttila, K. Linnainmaa, P. Pääkkö, Apoptosis and expression of apoptosis regulating proteins bcl-2, mcl-1, bcl-X, and bax in malignant mesothelioma, Clin. Cancer Res. 5 (1999) 3508-3515.

[36] S. Hopkins-Donaldson, R. Cathomas, A.P. Simões-Wüst, S. Kurtz, L. Belyanskya, R.A. Stahel, U. Zangemeister-Wittke, Induction of apoptosis and chemosensitization of mesothelioma cells by Bcl-2 and Bcl-xL antisense treatment, Int. J. Cancer 106 (2003) $160-166$.

[37] F.-X. Yu, K.-L. Guan, The Hippo pathway: regulators and regulations, Genes Dev. 27 (2013) 355-371.

[38] T. Mizuno, H. Murakami, M. Fujii, F. Ishiguro, I. Tanaka, Y. Kondo, S. Akatsuka, S. Toyokuni, K. Yokoi, H. Osada, Y. Sekido, YAP induces malignant mesothelioma cell proliferation by upregulating transcription of cell cycle-promoting genes, Oncogene 31 (2012) 5117-5122.

[39] M. Fujii, T. Toyoda, H. Nakanishi, Y. Yatabe, A. Sato, Y. Matsudaira, H. Ito, H. Murakami, Y. Kondo, E. Kondo, T. Hida, T. Tsujimura, H. Osada, Y. Sekido, TGF- $\beta$ synergizes with defects in the Hippo pathway to stimulate human malignant mesothelioma growth, J. Exp. Med. 209 (2012) 479-494.

[40] K. Saito-Diaz, T. Chen, X. Wang, C. Thorne, H. Wallace, A. Page-McCaw, E. Lee, The way Wnt works: components and mechanism, Growth Factors 31 (2013) 1-31.

[41] K. Uematsu, S. Kanazawa, L. You, B. He, Z. Xu, K. Li, B.M. Peterlin, F. McCormick, D.M. Jablons, Wnt pathway activation in mesothelioma: evidence of dishevelled overexpression and transcriptional activity of $\hat{I}^{2}$-catenin, Cancer Res. 63 (2003) 4547-4551.

[42] L.V. de Assis, M.C. Isoldi, The function, mechanisms, and role of the genes PTEN and TP53 and the effects of asbestos in the development of malignant mesothelioma: a review focused on the genes' molecular mechanisms, Tumor Biol. (2013) $1-13$.

[43] B. Kroczynska, R. Cutrone, M. Bocchetta, H. Yang, A.G. Elmishad, P. Vacek, M. Ramos-Nino, B.T. Mossman, H.I. Pass, M. Carbone, Crocidolite asbestos and SV40 are cocarcinogens in human mesothelial cells and in causing mesothelioma in hamsters, Proc. Natl. Acad. Sci. 103 (2006) 14128-14133.

44] M. Carbone, H.I. Pass, L. Miele, M. Bocchetta, New developments about the association of SV40 with human mesothelioma, Oncogene 22 (2003) 5173-5180. 
[45] N. Shivapurkar, T. Wiethege, I.I. Wistuba, E. Salomon, S. Milchgrub, K.M. Muller, A. Churg, H. Pass, A.F. Gazdar, Presence of simian virus 40 sequences in malignant mesotheliomas and mesothelial cell proliferations, J. Cell. Biochem. 76 (1999) 181-188.

[46] F. Lopez-Rios, P.B. Illei, V. Rusch, M. Ladanyi, Evidence against a role for SV40 infection in human mesotheliomas and high risk of false-positive PCR results owing to presence of SV40 sequences in common laboratory plasmids, Lancet 364 (2004) 1157-1166.

[47] M. Comar, N. Zanotta, G. Pesel, P. Visconti, I. Maestri, R. Rinaldi, S. Crovella, M. Cortale, R. De Zotti, M. Bovenzi, Asbestos and SV40 in malignant pleural mesothelioma from a hyperendemic area of north-eastern Italy, Tumori 98 (2012) 210-214.

[48] R. Hubner, E. Van Marck, Reappraisal of the strong association between simian virus 40 and human malignant mesothelioma of the pleura (Belgium), Cancer Causes Control 13 (2002) 121-129.

[49] M. Eom, J. Abdul-Ghafar, S. Park, J. Han, S. Hong, K. Kwon, E. Ko, L. Kim, W. Kim, S. Ha, K. Lee, C. Lee, H. Yoon, Y. Choi, M. Chung, S. Jung, No detection of simian virus 40 in malignant mesothelioma in Korea, Kor. J. Pathol. 47 (2013) 124-129.

[50] J. Hmeljak, I. Kern, A. Cör, No implication of Simian virus 40 in pathogenesis of malignant pleural mesothelioma in Slovenia, Tumori 96 (2010) 667-673.

[51] F. Qi, M. Carbone, H. Yang, G. Gaudino, Simian virus 40 transformation, malignant mesothelioma and brain tumors, Expert Rev. Respir. Med. 5 (2012) 683-697.

[52] C. Cicala, F. Pompetti, M. Carbone, SV40 induces mesotheliomas in hamsters, Am. J. Pathol. 142 (1993) 1524-1533.

[53] C. Robinson, I. van Bruggen, A. Segal, M. Dunham, A. Sherwood, F. Koentgen, B.W.S. Robinson, R.A. Lake, A novel SV40 TAg transgenic model of asbestos-induced mesothelioma: malignant transformation is dose dependent, Cancer Res. 66 (2006) 10786-10794.

[54] A.L. Cleaver, K. Bhamidipaty, B. Wylie, T. Connor, C. Robinson, B.W. Robinson, S.E. Mutsaers, R.A. Lake, Long-term exposure of mesothelial cells to SV40 and asbestos leads to malignant transformation and chemotherapy resistance, Carcinogenesis 35 (2) (2013) 407-414.

[55] M. Bocchetta, L. Miele, H. Pass, M. Carbone, Notch-1 induction, a novel activity of SV40 required for growth of SV40-transformed human mesothelial cells, Oncogene 22 (2003) 81-89.

[56] M. Bocchetta, S. Eliasz, M.A. De Marco, J. Rudzinski, L. Zhang, M. Carbone, The SV40 large T antigen-p53 complexes bind and activate the insulin-like growth factor-I promoter stimulating cell growth, Cancer Res. 68 (2008) 1022-1029.

[57] A. Catalano, M. Romano, S. Martinotti, A. Procopio, Enhanced expression of vascular endothelial growth factor (VEGF) plays a critical role in the tumor progression potential induced by simian virus 40 large T antigen, Oncogene 25 (2002) 2896-2900.

[58] R. Foddis, A. De Rienzo, D. Broccoli, M. Bocchetta, E. Stekala, P. Rizzo, A. Tosolini, J. Grobelny, S. Jhanwar, H. Pass, J. Testa, M. Carbone, SV40 infection induces telomerase activity in human mesothelial cells, Oncogene 21 (2002) 1434-1442.

[59] J.R. Pietruska, A.B. Kane, SV40 oncoproteins enhance asbestos-induced DNA double-strand breaks and abrogate senescence in murine mesothelial cells, Cancer Res. 67 (2007) 3637-3645.

[60] C. Rake, C. Gilham, J. Hatch, A. Darnton, J. Hodgson, J. Peto, Occupational, domestic and environmental mesothelioma risks in the British population: a case-control study, Br. J. Cancer 100 (2009) 1175-1183.

[61] D.L. Coffin, P.M. Cook, J.P. Creason, Relative mesothelioma induction in rats by mineral fibers: comparison with residual pulmonary mineral fiber number and epidemiology, Inhal. Toxicol. 4 (1992) 273-300.

[62] P. Sebastien, A. Gaudichet, J. Bignon, Y. Baris, Zeolite bodies in human lungs from Turkey, Lab. Invest. 44 (1981) 420-425.

[63] I. Baris, L. Simonato, M. Artvinli, F. Pooley, R. Saracci, J. Skidmore, C. Wagner, Epidemiological and environmental evidence of the health effects of exposure to erionite fibres: a four-year study in the Cappadocian region of Turkey, Int. J. Cancer 39 (1987) 10-17.

[64] P. Dumortier, L. Coplü, I. Broucke, S. Emri, T. Selcuk, V. de Maertelaer, P. De Vuyst, I. Baris, Erionite bodies and fibres in bronchoalveolar lavage fluid (BALF) of residents from Tuzköy, Cappadocia, Turkey, Occup. Environ. Med. 58 (2001) 261-266.

[65] E.B. Ilgren, F.D. Pooley, J.C. Larragoitia, M. Talamantes, G.L. Navarrete, E. Krauss, A.F. Breña, First confirmed erionite related mesothelioma in North America, Indoor Built Environ. 17 (2008) 567-568.

[66] C. Kliment, K. Clemens, T. Oury, North American erionite-associated mesothelioma with pleural plaques and pulmonary fibrosis: a case report, Int. J. Clin. Exp. Pathol 2 (2009) 407-410.

[67] M. Carbone, Y.I. Baris, P. Bertino, B. Brass, S. Comertpay, A.U. Dogan, G. Gaudino, S. Jube, S. Kanodia, C.R. Partridge, H.I. Pass, Z.S. Rivera, I. Steele, M. Tuncer, S. Way, H. Yang, A. Miller, Erionite exposure in North Dakota and Turkish villages with mesothelioma, Proc. Natl. Acad. Sci. 108 (33) (2011) 13611-13623.

[68] S. Jube, Z.S. Rivera, M.E. Bianchi, A. Powers, E. Wang, I. Pagano, H.I. Pass, G. Gaudino, M. Carbone, H. Yang, Cancer cell secretion of the DAMP protein HMGB1 supports progression in malignant mesothelioma, Cancer Res. 72 (2012) 3290-3301.

[69] M. Carbone, H. Yang, Molecular pathways: targeting mechanisms of asbestos and erionite carcinogenesis in mesothelioma, Clin. Cancer Res. 18 (2013) 598-604.

[70] Y. Wang, S. Faux, G. Hallden, D. Kirn, C. Houghton, N. Lemoine, G. Patrick, Interleukin1 beta and tumour necrosis factor-alpha promote the transformation of human immortalised mesothelial cells by erionite, Int. J. Oncol. 25 (2004) 173-180.

[71] J. Hillegass, J. Miller, M. MacPherson, C. Westbom, M. Sayan, J. Thompson, S. Macura, T. Perkins, S. Beuschel, V. Alexeeva, H. Pass, C. Steele, B. Mossman, A. Shukla, Asbestos and erionite prime and activate the NLRP3 inflammasome that stimulates autocrine cytokine release in human mesothelial cells, Part Fibre Toxicol. C7-39 (10) (2013) 1-14.
[72] M. Ruas, G. Peters, The p16INK4a/CDKN2A tumor suppressor and its relatives, Biochim. Biophys. Acta 1378 (1998) F115-F177.

[73] G. Thillainadesan, J.M. Chitilian, M. Isovic, J.N. Ablack, J.S. Mymryk, M. Tini, J Torchia, TGF-beta-dependent active demethylation and expression of the p15ink4b tumor suppressor are impaired by the ZNF217/CoREST complex, Mol. Cell 46 (2012) 636-649.

[74] P. Krimpenfort, A. Ijpenberg, J.Y. Song, M. van der Valk, M. Nawijn, J. Zevenhoven, A. Berns, p15Ink4b is a critical tumour suppressor in the absence of p16Ink4a, Nature 448 (2007) 943-946.

[75] P. Berggren, R. Kumar, S. Sakano, L. Hemminki, T. Wada, G. Steineck, J. Adolfsson, P. Larsson, U. Norming, H. WijkstrÃ $9 m$, K. Hemminki, Detecting homozygous deletions in the CDKN2A(p16INK4a)/ARF(p14ARF) gene in urinary bladder cancer using real-time quantitative PCR, Clin. Cancer Res. 9 (2003) 235-242.

[76] L.L. Chang, W.T. Yeh, S.Y. Yang, W.J. Wu, C.H. Huang, Genetic alterations of p16INK4a and p14ARF genes in human bladder cancer, J. Urol. 170 (2003) 595-600.

[77] V.L. Brown, C.A. Harwood, T. Crook, J.G. Cronin, D.P. Kelsell, C.M. Proby, p16INK4a and p14ARF tumor suppressor genes are commonly inactivated in cutaneous squamous cell carcinoma, J. Invest. Dermatol. 122 (2004) 1284-1292.

[78] J.L. Wang, B.Y. Zheng, X.D. Li, K. Nokelainen, T. Angstrom, M.S. Lindstrom, K.L Wallin, p16INK4A and p14ARF expression pattern by immunohistochemistry in human papillomavirus-related cervical neoplasia, Mod. Pathol. 18 (2005) 629-637.

[79] J.Q. Cheng, S.C. Jhanwar, W.M. Klein, D.W. Bell, W.-C. Lee, D.A. Altomare, T. Nobori, O.I. Olopade, A.J. Buckler, J.R. Testa, p16 Alterations and deletion mapping of 9p21p22 in malignant mesothelioma, Cancer Res. 54 (1994) 5547-5551.

[80] P.B. Illei, V.W. Rusch, M.F. Zakowski, M. Ladanyi, Homozygous deletion of CDKN2A and codeletion of the methylthioadenosine phosphorylase gene in the majority of pleural mesotheliomas, Clin. Cancer Res. 9 (2003) 2108-2113.

[81] F.B. Onofre, A.S. Onofre, N. Pomjanski, B. Buckstegge, H.J. Grote, A. Bocking, 9p21 Deletion in the diagnosis of malignant mesothelioma in serous effusions additional to immunocytochemistry, DNA-ICM, and AgNOR analysis, Cancer 114 (2008) 204-215.

[82] M. Takeda, T. Kasai, Y. Enomoto, M. Takano, K. Morita, E. Kadota, N. Iizuka, H. Maruyama, A. Nonomura, Genomic gains and losses in malignant mesothelioma demonstrated by FISH analysis of paraffin-embedded tissues, J. Clin. Pathol. 65 (2012) 77-82.

[83] S. Chiosea, A. Krasinskas, P.T. Cagle, K.A. Mitchell, D.S. Zander, S. Dacic, Diagnostic importance of 9p21 homozygous deletion in malignant mesotheliomas, Mod. Pathol. 21 (2008) 742-747.

[84] J.R. Fischer, U. Ohnmacht, N. Rieger, M. Zemaitis, C. Stoffregen, M. Kostrzewa, E. Buchholz, C. Manegold, H. Lahm, Promoter methylation of RASSF1A, RAR $\hat{I}^{2}$ and DAPK predict poor prognosis of patients with malignant mesothelioma, Lung Cancer 54 (2006) 109-116.

[85] T. Kamijo, F. Zindy, M.F. Roussel, D.E. Quelle, J.R. Downing, R.A. Ashmun, G. Grosveld, C.J. Sherr, Tumor suppression at the mouse INK4a locus mediated by the alternative reading frame product p19ARF, Cell 91 (1997) 649-659.

[86] N.E. Sharpless, N. Bardeesy, K.H. Lee, D. Carrasco, D.H. Castrillon, A.J. Aguirre, E.A. Wu, J.W. Horner, R.A. DePinho, Loss of p16Ink4a with retention of p19Arf predisposes mice to tumorigenesis, Nature 413 (2001) 86-91.

[87] M. Serrano, H. Lee, L. Chin, C. Cordon-Cardo, D. Beach, R.A. DePinho, Role of the INK4a locus in tumor suppression and cell mortality, Cell 85 (1996) 27-37.

[88] D.A. Altomare, C.W. Menges, J. Pei, L. Zhang, K.L. Skele-Stump, M. Carbone, A.B. Kane, J.R. Testa, Activated TNF-alpha/NF-kappaB signaling via down-regulation of Fas-associated factor 1 in asbestos-induced mesotheliomas from Arf knockout mice, Proc. Natl. Acad. Sci. U.S.A. 106 (2009) 3420-3425.

[89] D.A. Altomare, C.W. Menges, J. Xu, J. Pei, L. Zhang, A. Tadevosyan, E. NeumannDomer, Z. Liu, M. Carbone, I. Chudoba, A.J. Klein-Szanto, J.R. Testa, Losses of both products of the Cdkn2a/Arf locus contribute to asbestos-induced mesothelioma development and cooperate to accelerate tumorigenesis, PLoS One 6 (2011) e18828.

[90] S. Frizelle, J. Grim, J. Zhou, P. Gupta, D. Curiel, J. Geradts, R. Kratzke, Re-expression of p16INK4a in mesothelioma cells results in cell cycle arrest, cell death, tumor suppression and tumor regression, Oncogene 16 (1998) 3087-3095.

[91] S. Frizelle, J. Rubins, J. Zhou, D. Curiel, R. Kratzke, Gene therapy of established mesothelioma xenografts with recombinant p16INK4a adenovirus, Cancer Gene Ther. 7 (2000) 1421-1425

[92] C. Yang, L. You, Y. Lin, C. Lin, F. McCormick, D. Jablons, A comparison analysis of anti-tumor efficacy of adenoviral gene replacement therapy (p14ARF and p16INK4A) in human mesothelioma cells, Anticancer Res. 23 (2003) 33-38.

[93] Y. Tada, H. Shimada, K. Hiroshima, M. Tagawa, A potential therapeutic strategy for malignant mesothelioma with gene medicine, Biomed. Res. Int. 2013 (2013) 8.

[94] D.G.R. Evans, Neurofibromatosis 2 [bilateral acoustic neurofibromatosis, central neurofibromatosis, NF2, neurofibromatosis type II], Genet. Med. 11 (2009) 599.

[95] Y. Sekido, H.I. Pass, S. Bader, D.J.Y. Mew, M.F. Christman, A.F. Gazdar, J.D. Minna, Neurofibromatosis type 2 (NF2) gene is somatically mutated in mesothelioma but not in lung cancer, Cancer Res. 55 (1995) 1227-1231.

[96] A.B. Bianchi, S.I. Mitsunaga, J.Q. Cheng, W.M. Klein, S.C. Jhanwar, B. Seizinger, N Kley, A.J. Klein-Szanto, J.R. Testa, High frequency of inactivating mutations in the neurofibromatosis type 2 gene (NF2) in primary malignant mesotheliomas, Proc. Natl. Acad. Sci. U.S.A. 92 (1995) 10854-10858.

[97] P. Andujar, J.C. Pairon, A. Renier, A. Descatha, I. Hysi, I. Abd-Alsamad, M.A. BillonGalland, H.ln. Blons, B.n.d. Clin, C. Danel, D. Debrosse, F.o. Galateau-SallÃ@), B. Housset, P. Laurent-Puig, F.o. Le Pimpec-Barthes, M. Letourneux, I. Monnet, J.F.o. RÃ@gnard, P. Validire, J. Zucman-Rossi, M.C. Jaurand, D. Jean, Differential mutation profiles and similar intronic TP53 polymorphisms in asbestos-related lung cancer and pleural mesothelioma, Mutagenesis 28 (2013) 323-331. 
[98] H. Nemoto, G. Tate, K. Kishimoto, M. Saito, A. Shirahata, T. Umemoto, T. Matsubara, T. Goto, H. Mizukami, G. Kigawa, T. Mitsuya, K. Hibi, Heterozygous loss of NF2 is an early molecular alteration in well-differentiated papillary mesothelioma of the peritoneum, Cancer Genet. 205 (2012) 594-598.

[99] M. Guled, L. Lahti, P.M. Lindholm, K. Salmenkivi, I. Bagwan, A.G. Nicholson, S Knuutila, CDKN2A, NF2, and JUN are dysregulated among other genes by miRNAs in malignant mesothelioma-a miRNA microarray analysis, Genes Chromosom. Cancer 48 (2009) 615-623.

[100] J. Jongsma, E. van Montfort, M. Vooijs, J. Zevenhoven, P. Krimpenfort, M. van der Valk, M. van de Vijver, A. Berns, A conditional mouse model for malignant mesothelioma, Cancer Cell 13 (2008) 261-271.

[101] K. Ikeda, Y. Saeki, C. Gonzalez-Agosti, V. Ramesh, E.A. Chiocca, Inhibition of NF2-negative and NF2-positive primary human meningioma cell proliferation by overexpression of merlin due to vector-mediated gene transfer, J. Neurosurg. 91 (1999) 85-92.

[102] K.M.M. Schulze, C.O. Hanemann, H.W. Müller, H. Hanenberg, Transduction of wild-type merlin into human schwannoma cells decreases schwannoma cell growth and induces apoptosis, Hum. Mol. Genet. 11 (2002) 69-76.

[103] J. Fraenzer, H. Pan, L.J. Minimo, G. Smith, D. Knauer, G. Hung, Overexpression of the NF2 gene inhibits schwannoma cell proliferation through promoting PDGFR degradation, Int. J. Oncol. 2003 (2003) 1493-1500.

[104] F.C. Morales, J.R. Molina, Y. Hayashi, M.-M. Georgescu, Overexpression of ezrin inactivates NF2 tumor suppressor in glioblastoma, Neuro-Oncology 12 (2010) 528-539.

[105] P. Poulikakos, G. Xiao, R. Gallagher, S. Jablonski, S. Jhanwar, J. Testa, Re-expression of the tumor suppressor NF2/merlin inhibits invasiveness in mesothelioma cells and negatively regulates FAK, Oncogene 25 (2006) 5960-5980.

[106] G.H. Xiao, R. Gallagher, J. Shetler, K. Skele, D.A. Altomare, R.G. Pestell, S. Jhanwar, J.R. Testa, The NF2 tumor suppressor gene product, merlin, inhibits cell proliferation and cell cycle progression by repressing cyclin D1 expression, Mol. Cell. Biol. 25 (2005) 2384-2394.

[107] I. Roushdy-Hammady, J. Siegel, S. Emri, J.R. Testa, M. Carbone, Genetic susceptibility factor and malignant mesothelioma in the Cappadocian region of Turkey, Lancet 357 (2001) 444-445.

[108] A.U. Dogan, Y.I. Baris, M. Dogan, S. Emri, I. Steele, A.G. Elmishad, M. Carbone, Genetic predisposition to fiber carcinogenesis causes a mesothelioma epidemic in Turkey, Cancer Res. 66 (2006) 5063-5068.

[109] M. Metintas, G. Hillerdal, S. Metintas, P. Dumortier, Endemic malignant mesothelioma: exposure to erionite is more important than genetic factors, Arch. Environ. Occup. Health 65 (2010) 86-93.

[110] J.R. Testa, M. Cheung, J. Pei, J.E. Below, Y. Tan, E. Sementino, N.J. Cox, A.U. Dogan, H.I. Pass, S. Trusa, M. Hesdorffer, M. Nasu, A. Powers, Z. Rivera, S. Comertpay, M. Tanji, G. Gaudino, H. Yang, M. Carbone, Germline BAP1 mutations predispose to malignant mesothelioma, Nat. Genet. 43 (2011) 1022-1025.

[111] T. Popova, L. Hebert, V. Jacquemin, S. Gad, V. Caux-Moncoutier, C. Dubois-d Enghien, B. Richaudeau, X. Renaudin, J. Sellers, A. Nicolas, X. Sastre-Garau, L. Desjardins, G. Gyapay, V. Raynal, Olga M. Sinilnikova, N. Andrieu, E. Manié, A. de Pauw, P. Gesta, V. Bonadona, Christine M. Maugard, C. Penet, M.F. Avril, E. Barillot, O. Cabaret, O. Delattre, S. Richard, O. Caron, M. Benfodda, H.-H. Hu, N. Soufir, B. Bressac-de Paillerets, D. Stoppa-Lyonnet, M.-H. Stern, Germline BAP1 mutations predispose to renal cell carcinomas, Am. J. Hum. Genet. 92 (2013) 974-980.

[112] M. Bott, M. Brevet, B.S. Taylor, S. Shimizu, T. Ito, L. Wang, J. Creaney, R.A. Lake, M.F. Zakowski, B. Reva, C. Sander, R. Delsite, S. Powell, Q. Zhou, R. Shen, A. Olshen, V. Rusch, M. Ladanyi, The nuclear deubiquitinase BAP1 is commonly inactivated by somatic mutations and 3p21.1 losses in malignant pleural mesothelioma, Nat. Genet. 43 (2011) 668-672.

[113] Y. Yoshikawa, A. Sato, T. Tsujimura, M. Emi, T. Morinaga, K. Fukuoka, S. Yamada, A. Murakami, N. Kondo, S. Matsumoto, Y. Okumura, F. Tanaka, S. Hasegawa, T. Nakano, T. Hashimoto-Tamaoki, Frequent inactivation of the BAP1 gene in epithelioid-type malignant mesothelioma, Cancer Sci. 103 (2012) 868-874.

[114] M. Zauderer, M. Bott, R. McMillan, C. Sima, V. Rusch, L. Krug, M. Ladanyi, Clinical characteristics of patients with malignant pleural mesothelioma harboring somatic BAP1 mutations, J. Thorac. Oncol. 8 (2013) 1430-1433.

[115] L. Arzt, F. Quehenberger, I. Halbwedl, T. Mairinger, H. Popper, BAP1 protein is progression factor in malignant pleural mesothelioma, Pathol. Oncol. Res. (2013) $1-7$.

[116] R. Murali, T. Wiesner, R. Scolyer, Tumours associated with BAP1 mutations, Pathology 45 (2013) 116-126.

[117] R. Pilarski, C.M. Cebulla, J.B. Massengill, K. Rai, T. Rich, L. Strong, B. McGillivray, M.-J. Asrat, F.H. Davidorf, M.H. Abdel-Rahman, Expanding the clinical phenotype of hereditary BAP1 cancer predisposition syndrome, reporting three new cases, Genes Chromosom. Cancer 53 (2) (2013) 177-182.

[118] R.W. Justice, O. Zilian, D.F. Woods, M. Noll, P.J. Bryant, The Drosophila tumor suppressor gene warts encodes a homolog of human myotonic dystrophy kinase and is required for the control of cell shape and proliferation, Genes Dev. 9 (1995) 534-546.

[119] N. Yabuta, T. Fujii, N.G. Copeland, D.J. Gilbert, N.A. Jenkins, H. Nishiguchi, Y. Endo, S. Toji, H. Tanaka, Y. Nishimune, H. Nojima, Structure, expression, and chromosome mapping of LATS2, a mammalian homologue of the Drosophila tumor suppressor gene lats/warts, Genomics 63 (2000) 263-270.

[120] C.F. Chen, S.H. Yeh, D.S. Chen, P.J. Chen, Y.S. Jou, Molecular genetic evidence supporting a novel human hepatocellular carcinoma tumor suppressor locus at 13q12.11, Genes Chromosom. Cancer 44 (2005) 320-328.

[121] Y. Aylon, D. Michael, A. Shmueli, N. Yabuta, H. Nojima, M. Oren, A positive feedback loop between the p53 and Lats2 tumor suppressors prevents tetraploidization, Genes Dev. 20 (2006) 2687-2700.
[122] Y. Aylon, Y. Ofir-Rosenfeld, N. Yabuta, E. Lapi, H. Nojima, X. Lu, M. Oren, The Lats2 tumor suppressor augments p53-mediated apoptosis by promoting the nuclear proapoptotic function of ASPP1, Genes Dev. 24 (2010) 2420-2429.

[123] S. Visser, X. Yang, LATS tumor suppressor: a new governor of cellular homeostasis, Cell Cycle 9 (2010) 3922-3933.

[124] B.C. Christensen, E.A. Houseman, J.J. Godleski, C.J. Marsit, J.L. Longacker, C.R. Roelofs, M.R. Karagas, M.R. Wrensch, R.-F. Yeh, H.H. Nelson, J.L. Wiemels, S. Zheng, J.K. Wiencke, R. Bueno, D.J. Sugarbaker, K.T. Kelsey, Epigenetic profiles distinguish pleural mesothelioma from normal pleura and predict lung asbestos burden and clinical outcome, Cancer Res. 69 (2009) 227-234.

[125] Y. Goto, K. Shinjo, Y. Kondo, L. Shen, M. Toyota, H. Suzuki, W. Gao, B. An, M. Fujii, H. Murakami, H. Osada, T. Taniguchi, N. Usami, M. Kondo, Y. Hasegawa, K. Shimokata, K. Matsuo, T. Hida, N. Fujimoto, T. Kishimoto, J.-P.J. Issa, Y. Sekido, Epigenetic profiles distinguish malignant pleural mesothelioma from lung adenocarcinoma, Cancer Res. 69 (2009) 9073-9082.

[126] J.R. Fischer, U. Ohnmacht, N. Rieger, M. Zemaitis, C. Stoffregen, M. Kostrzewa, E. Buchholz, C. Manegold, H. Lahm, Promoter methylation of RASSF1A, RAR $\beta$ and DAPK predict poor prognosis of patients with malignant mesothelioma, Lung Cancer 54 (2006) 109-116.

[127] F. Vandermeers, S. Neelature Sriramareddy, C. Costa, R. Hubaux, J.-P. Cosse, L. Willems, The role of epigenetics in malignant pleural mesothelioma, Lung Cancer 81 (2013) 311-318(Amsterdam, Netherlands).

[128] S.V. Ivanov, C.M.V. Goparaju, P. Lopez, J. Zavadil, G. Toren-Haritan, S. Rosenwald, M. Hoshen, A. Chajut, D. Cohen, H.I. Pass, Pro-tumorigenic effects of miR-31 loss in mesothelioma, J. Biol. Chem. 285 (2010) 22809-22817.

[129] G. Reid, M.E. Pel, M.B. Kirschner, Y.Y. Cheng, N. Mugridge, J. Weiss, M. Williams, C. Wright, J.J.B. Edelman, M.P. Vallely, B.C. McCaughan, S. Klebe, H. Brahmbhatt, J.A. MacDiarmid, N. van Zandwijk, Restoring expression of miR-16: a novel approach to therapy for malignant pleural mesothelioma, Ann. Oncol. 24 (12) (2013) 3128-3135.

[130] G.V. Gee, D.C. Koestler, B.C. Christensen, D.J. Sugarbaker, D. Ugolini, G.P. Ivaldi, M.B. Resnick, E.A. Houseman, K.T. Kelsey, C.J. Marsit, Downregulated microRNAs in the differential diagnosis of malignant pleural mesothelioma, Int. J. Cancer 127 (2010) 2859-2869.

[131] M.B. Kirschner, Y.Y. Cheng, B. Badrian, S.C. Kao, J. Creaney, J.J. Edelman, N.J. Armstrong, M.P. Vallely, A.W. Musk, B.W. Robinson, B.C. McCaughan, S. Klebe, S.E. Mutsaers, N. van Zandwijk, G. Reid, Increased circulating miR-625-3p: a potential biomarker for patients with malignant pleural mesothelioma, J Thorac Oncol 7 (2012) 1184-1191.

[132] T. Muraoka, J. Soh, S. Toyooka, K. Aoe, N. Fujimoto, S. Hashida, Y. Maki, N. Tanaka, K. Shien, M. Furukawa, H. Yamamoto, H. Asano, K. Tsukuda, T. Kishimoto, T. Otsuki, S. Miyoshi, The degree of microRNA-34b/c methylation in serum-circulating DNA is associated with malignant pleural mesothelioma, Lung Cancer 82 (3) (2013) 485-490.

[133] M. Cioce, F. Ganci, V. Canu, A. Sacconi, F. Mori, C. Canino, E. Korita, B. Casini, G. Alessandrini, A. Cambria, M.A. Carosi, R. Blandino, V. Panebianco, F. Facciolo, P. Visca, S. Volinia, P. Muti, S. Strano, C.M. Croce, H.I. Pass, G. Blandino, Protumorigenic effects of mir-145 loss in malignant pleural mesothelioma, Oncogene (2013), in press, (Epub ahead of print).

[134] N. Tapon, K.F. Harvey, D.W. Bell, D.C.R. Wahrer, T.A. Schiripo, D.A. Haber, I.K. Hariharan, salvador Promotes both cell cycle exit and apoptosis in Drosophila and is mutated in human cancer cell lines, Cell 110 (2002) 467-478.

[135] L. Lu, Y. Li, S.M. Kim, W. Bossuyt, P. Liu, Q. Qiu, Y. Wang, G. Halder, M.J. Finegold, J.-S. Lee, R.L. Johnson, Hippo signaling is a potent in vivo growth and tumor suppressor pathway in the mammalian liver, Proc. Natl. Acad. Sci. 107 (2010) 1437-1442.

[136] K. Shigemitsu, Y. Sekido, N. Usami, S. Mori, M. Sato, Y. Horio, Y. Hasegawa, S. Bader, A. Gazdar, J. Minna, T. Hida, H. Yoshioka, M. Imaizumi, Y. Ueda, M. Takahashi, K. Shimokata, Genetic alteration of the beta-catenin gene (CTNNB1) in human lung cancer and malignant mesothelioma and identification of a new 3p21.3 homozygous deletion, Oncogene 20 (2001) 4249-4257.

[137] N. Usami, Y. Sekido, O. Maeda, K. Yamamoto, J. Minna, Y. Hasegawa, H. Yoshioka, M. Imaizumi, Y. Ueda, M. Takahashi, K. S., Beta-catenin inhibits cell growth of a malignant mesothelioma cell line, $\mathrm{NCI}-\mathrm{H} 28$, with a 3p21.3 homozygous deletion, Oncogene 22 (2003) 7923-7930.

[138] M. You, J. Varona-Santos, S. Singh, D.J. Robbins, N. Savaraj, D.M. Nguyen, Targeting of the Hedgehog signal transduction pathway suppresses survival of malignant pleural mesothelioma cells in vitro, J. Thorac. Cardiovasc. Surg. 147 (1) (2013) 508-516.

[139] C.B. Lim, C.M. Prêle, H.M. Cheah, Y.Y. Cheng, S. Klebe, G. Reid, D.N. Watkins, S. Baltic, P.J. Thompson, S.E. Mutsaers, Mutational analysis of hedgehog signaling pathway genes in human malignant mesothelioma, PLoS One 8 (2013) e66685.

[140] G. Klorin, E. Rozenblum, O. Glebov, R.L. Walker, Y. Park, P.S. Meltzer, I.R. Kirsch, F.J. Kaye, A.V. Roschke, Integrated high-resolution array CGH and SKY analysis of homozygous deletions and other genomic alterations present in malignant mesothelioma cell lines, Cancer Genet. 206 (2013) 191-205.

[141] C. Savvidis, M. Koutsilieris, Circadian rhythm disruption in cancer biology, Mol. Med. 18 (2012) 1249-1260

[142] R.G. Stevens, Circadian disruption and breast cancer: from melatonin to clock genes, Epidemiology 16 (2005) 254-258

[143] S. Giacchetti, G. Bjarnason, C. Garufi, D. Genet, S. Iacobelli, M. Tampellini, R. Smaaland, C. Focan, B. Coudert, Y. Humblet, J.L. Canon, A. Adenis, G.L. Re, C. Carvalho, J. Schueller, N. Anciaux, M.A. Lentz, B.t. Baron, T. Gorlia, F. Lévi, Phase III trial comparing 4-day chronomodulated therapy versus 2-day conventional delivery of fluorouracil, leucovorin, and oxaliplatin as first-line chemotherapy of metastatic colorectal cancer: the European Organisation for Research and Treatment of Cancer Chronotherapy Group, J. Clin. Oncol. 24 (2006) 3562-3569. 
[144] O.D. Røe, E. Anderssen, E. Helge, C.H. Pettersen, K.S. Olsen, H. Sandeck, R. Haaverstad, S. Lundgren, E. Larsson, Genome-wide profile of pleural mesothelioma versus parietal and visceral pleura: the emerging gene portrait of the mesothelioma phenotype, PLoS One 4 (2009) e6554.

[145] M. Elshazley, M. Sato, T. Hase, R. Yamashita, K. Yoshida, S. Toyokuni, F. Ishiguro, H. Osada, Y. Sekido, K. Yokoi, N. Usami, D.S. Shames, M. Kondo, A.F. Gazdar, J.D. Minna, Y. Hasegawa, The circadian clock gene BMAL1 is a novel therapeutic target for malignant pleural mesothelioma, Int. J. Cancer 131 (2012) 2820-2831.

[146] M. Brevet, S. Shimizu, M.J. Bott, N. Shukla, Q. Zhou, A.B. Olshen, V. Rusch, M. Ladanyi, Coactivation of receptor tyrosine kinases in malignant mesothelioma as a rationale for combination targeted therapy, J. Thorac. Oncol. 6 (2011) 864-874.

[147] M.A. Lemmon, J. Schlessinger, Cell signaling by receptor tyrosine kinases, Cell 141 (2010) 1117-1134.

[148] V. Agarwal, M.J. Lind, L. Cawkwell, Targeted epidermal growth factor receptor therapy in malignant pleural mesothelioma: where do we stand? Cancer Treat. Rev. 37 (2011) 533-542.

[149] H. Kothmaier, F. Quehenberger, I. Halbwedl, P. Morbini, F. Demirag, H. Zeren, C.E. Comin, B. Murer, P.T. Cagle, R. Attanoos, A.R. Gibbs, F. Galateau-Salle, H.H. Popper, EGFR and PDGFR differentially promote growth in malignant epithelioid mesothelioma of short and long term survivors, Thorax 63 (2008) 345-351.

[150] A. Destro, G.L. Ceresoli, M. Falleni, P.A. Zucali, E. Morenghi, P. Bianchi, C. Pellegrini, N. Cordani, V. Vaira, M. Alloisio, A. Rizzi, S. Bosari, M. Roncalli, EGFR overexpression in malignant pleural mesothelioma: an immunohistochemical and molecular study with clinico-pathological correlations, Lung Cancer 51 (2006) 207-215(Amsterdam, Netherlands).

[151] R. Govindan, R.A. Kratzke, J.E. Herndon, G.A. Niehans, R. Vollmer, D. Watson, M.R Green, H.L. Kindler, Gefitinib in patients with malignant mesothelioma: a phase II study by the cancer and leukemia group B, Clin. Cancer Res. 11 (2005) 2300-2304

[152] L.L. Garland, C. Rankin, D.R. Gandara, S.E. Rivkin, K.M. Scott, R.B. Nagle, A.J.P. Klein-Szanto, J.R. Testa, D.A. Altomare, E.C. Borden, Phase II study of Erlotinib in patients with malignant pleural mesothelioma: a southwest oncology group study, J. Clin. Oncol. 25 (2007) 2406-2413.

[153] C. Linder, S. Linder, E. Munck-Wikland, H. Strander, Independent expression of serum vascular endothelial growth factor (VEGF) and basic fibroblast growth factor (bFGF) in patients with carcinoma and sarcoma, Anticancer Res. 18 (1998) 2063-2068.

[154] S. Kumar-Singh, J. Weyler, M.J. Martin, P.B. Vermeulen, E. Van Marck, Angiogenic cytokines in mesothelioma: a study of VEGF, FGF-1 and -2, and TGF beta expression, J. Pathol. 189 (1999) 72-78.

[155] F. Demirag, E. Uì̀nsal, A. Yilmaz, A. Cì̧agìłlar, Prognostic significance of vascular endothelial growth factor, tumor necrosis, and mitotic activity index in malignant pleural mesothelioma*, Chest J. 128 (2005) 3382-3387.

[156] K. Aoe, A. Hiraki, T. Tanaka, K.-I. Gemba, K. Taguchi, T. Murakami, N. Sueoka, T. Kamei, H. Ueoka, K. Sugi, T. Yoshino, T. Kishimoto, Expression of vascular endothelial growth factor in malignant mesothelioma, Anticancer Res. 26 (2006) 4833-4836.

[157] R.E. Favoni, A. Daga, P. Malatesta, T. Florio, Preclinical studies identify novel targeted pharmacological strategies for treatment of human malignant pleural mesothelioma, Br. J. Pharmacol. 166 (2012) 532-553.

[158] D.M. Jackman, H.L. Kindler, B.Y. Yeap, P. Fidias, R. Salgia, J. Lucca, L.K. Morse, P.A. Ostler, B.E. Johnson, P.A. Jänne, Erlotinib plus bevacizumab in previously treated patients with malignant pleural mesothelioma, Cancer 113 (2008) 808-814.

[159] B.A. Whitson, R.A. Kratzke, Molecular pathways in malignant pleural mesothelioma, Cancer Lett. 239 (2006) 183-189.

[160] C.D. Hoang, J. D'Cunha, M.G. Kratzke, C.E. Casmey, S.P. Frizelle, M.A. Maddaus, R.A. Kratzke, Gene expression profiling identifies matriptase overexpression in malignant mesothelioma, Chest 125 (2004) 1843-1852.

[161] C.D. Hoang, X. Zhang, P.D. Scott, T.J. Guillaume, M.A. Maddaus, D. Yee, R.A. Kratzke, Selective activation of insulin receptor substrate- 1 and -2 in pleural mesothelioma cells: association with distinct malignant phenotypes, Cancer Res. 64 (2004) 7479-7485.

[162] N. Kalra, J. Zhang, Y. Yu, M. Ho, M. Merino, L. Cao, R. Hassan, Efficacy of anti-insulinlike growth factor I receptor monoclonal antibody cixutumumab in mesothelioma is highly correlated with insulin growth factor-I receptor sites/cell, Int. J. Cancer 131 (2012) 2143-2152.

[163] H.I. Pass, C. Goparaju, S. Ivanov, J. Donington, M. Carbone, M. Hoshen, D. Cohen, A. Chajut, S. Rosenwald, H. Dan, S. Benjamin, R. Aharonov, hsa-miR-29c* is linked to the prognosis of malignant pleural mesothelioma, Cancer Res. 70 (2010) 1916-1924.

[164] S. Busacca, S. Germano, L. De Cecco, M. Rinaldi, F. Comoglio, F. Favero, B. Murer, L. Mutti, M. Pierotti, G. Gaudino, microRNA signature of malignant mesothelioma with potential diagnostic and prognostic implications, Am. J. Respir. Cell Mol. Biol. 42 (2010) 312-319.

[165] I. Thirkettle, P. Harvey, P.S. Hasleton, R.Y. Ball, R.M. Warn, Immunoreactivity for cadherins, $\mathrm{HGF} / \mathrm{SF}$, met, and erbB-2 in pleural malignant mesotheliomas, Histopathology 36 (2000) 522-528.

[166] R. Jagadeeswaran, P.C. Ma, T.Y. Seiwert, S. Jagadeeswaran, O. Zumba, V. Nallasura, S. Ahmed, R. Filiberti, M. Paganuzzi, R. Puntoni, R.A. Kratzke, G.J. Gordon, D.J. Sugarbaker, R. Bueno, V. Janamanchi, V.P. Bindokas, H.L. Kindler, R. Salgia, Functional analysis of c-Met/hepatocyte growth factor pathway in malignant pleural mesothelioma, Cancer Res. 66 (2006) 352-361.

[167] K. Kawaguchi, H. Murakami, T. Taniguchi, M. Fujii, S. Kawata, T. Fukui, Y. Kondo, H. Osada, N. Usami, K. Yokoi, Y. Ueda, Y. Yatabe, M. Ito, Y. Horio, T. Hida, Y. Sekido, Combined inhibition of MET and EGFR suppresses proliferation of malignant mesothelioma cells, Carcinogenesis 30 (2009) 1097-1105.

[168] T. Mukohara, G. Civiello, I.J. Davis, M.L. Taffaro, J. Christensen, D.E. Fisher, B.E. Johnson, P.A. Jänne, Inhibition of the Met receptor in mesothelioma, Clin. Cancer Res. 11 (2005) 8122-8130.

[169] J.A. McCubrey, L.S. Steelman, W.H. Chappell, S.L. Abrams, E.W.T. Wong, F. Chang, B. Lehmann, D.M. Terrian, M. Milella, A. Tafuri, F. Stivala, M. Libra, J. Basecke, C.
Evangelisti, A.M. Martelli, R.A. Franklin, Roles of the Raf/MEK/ERK pathway in cell growth, malignant transformation and drug resistance, Biochim. Biophys. Acta, Mol. Cell. Res. 1773 (2007) 1263-1284.

[170] D. Díez, F. Sánchez-Jiménez, J. Ranea, Evolutionary expansion of the Ras switch regulatory module in eukaryotes, Nucleic Acids Res. 39 (13) (2011) 5526-5537.

[171] L. Santarpia, S.M. Lippman, A.K. El-Naggar, Targeting the MAPK-RAS-RAF signaling pathway in cancer therapy, Expert Opin. Ther. Targets 16 (2012) 103-119.

[172] Y. Mebratu, Y. Tesfaigzi, How ERK1/2 activation controls cell proliferation and cell death: is subcellular localization the answer? Cell Cycle 8 (2009) 1168-1175.

[173] H. Davies, G.R. Bignell, C. Cox, P. Stephens, S. Edkins, S. Clegg, J. Teague, H Woffendin, M.J. Garnett, W. Bottomley, N. Davis, E. Dicks, R. Ewing, Y. Floyd, K. Gray, S. Hall, R. Hawes, J. Hughes, V. Kosmidou, A. Menzies, C. Mould, A. Parker, C. Stevens, S. Watt, S. Hooper, R. Wilson, H. Jayatilake, B.A. Gusterson, C. Cooper J. Shipley, D. Hargrave, K. Pritchard-Jones, N. Maitland, G. Chenevix-Trench, G.J. Riggins, D.D. Bigner, G. Palmieri, A. Cossu, A. Flanagan, A. Nicholson, J.W. Ho, S.Y. Leung, S.T. Yuen, B.L. Weber, H.F. Seigler, T.L. Darrow, H. Paterson, R. Marais, C.J. Marshall, R. Wooster, M.R. Stratton, P.A. Futreal, Mutations of the BRAF gene in human cancer, Nature 417 (2002) 949-954

[174] M.d. Melo, M.W. Gerbase, J. Curran, J.C. Pache, Phosphorylated extracellular signal-regulated kinases are significantly increased in malignant mesothelioma, J. Histochem. Cytochem. 54 (2006) 855-861.

[175] L. Vintman, S. Nielsen, A. Berner, R. Reich, B. Davidson, Mitogen-activated protein kinase expression and activation does not differentiate benign from malignant mesothelial cells, Cancer 103 (2005) 2427-2433.

[176] C.L. Zanella, J. Posada, T.R. Tritton, B.T. Mossman, Asbestos causes stimulation of the extracellular signal-regulated kinase 1 mitogen-activated protein kinase cascade after phosphorylation of the epidermal growth factor receptor, Cancer Res. 56 (1996) 5334-5338.

177] A.B. Cummins, C. Palmer, B.T. Mossman, D.J. Taatjes, Persistent localization of activated extracellular signal-regulated kinases (ERK1/2) is epithelial cell-specific in an inhalation model of asbestosis, Am. J. Pathol. 162 (2003) 713-720.

[178] A. Shukla, J.M. Hillegass, M.B. MacPherson, S.L. Beuschel, P.M. Vacek, K.J. Butnor, H.I Pass, M. Carbone, J.R. Testa, N.H. Heintz, B.T. Mossman, ERK2 is essential for the growth of human epithelioid malignant mesotheliomas, Int. J. Cancer 129 (2011) 1075-1086.

[179] R. Katso, K. Okkenhaug, K. Ahmadi, S. White, J. Timms, M.D. Waterfield, Cellular function of phosphoinositide 3-kinases: implications for development, immunity, homeostasis, and cancer, Annu. Rev. Cell Dev. Biol. 17 (2001) 615-675.

[180] J.A. Engelman, J. Luo, L.C. Cantley, The evolution of phosphatidylinositol 3-kinases as regulators of growth and metabolism, Nat. Rev. Genet. 7 (2006) 606-619.

[181] N. Chalhoub, S.J. Baker, PTEN and the PI3-kinase pathway in cancer, Annu. Rev. Pathol. 4 (2009) 127-150.

[182] M. Chen, A. Cassidy, J. Gu, G.L. Delclos, F. Zhen, H. Yang, M.A. Hildebrandt, J. Lin, Y. Ye, R.M. Chamberlain, C.P. Dinney, X. Wu, Genetic variations in PI3K-AKT-mTOR pathway and bladder cancer risk, Carcinogenesis 30 (2009) 2047-2052.

[183] T.L. Yuan, L.C. Cantley, PI3K pathway alterations in cancer: variations on a theme, Oncogene 27 (2008) 5497-5510.

[184] B.D. Manning, L.C. Cantley, AKT/PKB signaling: navigating downstream, Cell 129 (2007) 1261-1274.

[185] A. Mora, D. Komander, D.M. van Aalten, D.R. Alessi, PDK1, the master regulator of AGC kinase signal transduction, Semin. Cell Dev. Biol. 15 (2004) 161-170.

[186] C.B. Ching, D.E. Hansel, Expanding therapeutic targets in bladder cancer: the PI3K/Akt/mTOR pathway, Lab. Invest. 90 (2010) 1406-1414.

[187] N. Sonenberg, A.C. Gingras, The mRNA 5' cap-binding protein eIF4E and control of cell growth, Curr. Opin. Cell Biol. 10 (1998) 268-275.

[188] N. Pullen, G. Thomas, The modular phosphorylation and activation of p70s6k, FEBS Lett. 410 (1997) 78-82.

[189] M.E. Ramos-Nino, G. Vianale, T. Sabo-Attwood, L. Mutti, C. Porta, N. Heintz, B.T. Mossman, Human mesothelioma cells exhibit tumor cell-specific differences in phosphatidylinositol 3-kinase/AKT activity that predict the efficacy of Onconase, Mol. Cancer Ther. 4 (2005) 835-842.

[190] Y. Mamane, E. Petroulakis, L. Rong, K. Yoshida, L.W. Ler, N. Sonenberg, eIF4E-from translation to transformation, Oncogene 23 (2004) 3172-3179.

[191] G.G. Chiang, R.T. Abraham, Targeting the mTOR signaling network in cancer, Trends Mol. Med. 13 (2007) 433-442.

[192] C. Eng, PTEN: one gene, many syndromes, Hum. Mutat. 22 (2003) 183-198.

193] S. Tanno, S. Tanno, Y. Mitsuuchi, D.A. Altomare, G.H. Xiao, J.R. Testa, AKT activation up-regulates insulin-like growth factor I receptor expression and promotes invasiveness of human pancreatic cancer cells, Cancer Res. 61 (2001) 589-593.

[194] Y. Samuels, Z. Wang, A. Bardelli, N. Silliman, J. Ptak, S. Szabo, H. Yan, A. Gazdar, S.M. Powell, G.J. Riggins, J.K. Willson, S. Markowitz, K.W. Kinzler, B. Vogelstein, V.E. Velculescu, High frequency of mutations of the PIK3CA gene in human cancers, Science 304 (2004) 554.

[195] A.-x. Liu, J.R. Testa, T.C. Hamilton, R. Jove, S.V. Nicosia, J.Q. Cheng, AKT2, a member of the protein kinase B family, is activated by growth factors, v-Ha-ras, and v-src through phosphatidylinositol 3-kinase in human ovarian epithelial cancer cells, Cancer Res. 58 (1998) 2973-2977.

[196] B. Actor, J.M. Cobbers, R. Buschges, M. Wolter, C.B. Knobbe, P. Lichter, G. Reifenberger, R.G. Weber, Comprehensive analysis of genomic alterations in gliosarcoma and its two tissue components, Gene Chromosome Cancer 34 (2002) 416-427.

[197] C.B. Knobbe, G. Reifenberger, Genetic alterations and aberrant expression of genes related to the phosphatidyl-inositol-3'-kinase/protein kinase B (Akt) signal transduction pathway in glioblastomas, Brain Pathol. 13 (2003) 507-518.

[198] J.M. Pedrero, D.G. Carracedo, C.M. Pinto, A.H. Zapatero, J.P. Rodrigo, C.S. Nieto, M.V. Gonzalez, Frequent genetic and biochemical alterations of the PI 3-K/AKT/PTEN pathway in head and neck squamous cell carcinoma, Int. J. Cancer 114 (2005) 242-248. 
[199] L.M. Chow, S.J. Baker, PTEN function in normal and neoplastic growth, Cancer Lett. 241 (2006) 184-196.

[200] K.-U. Kim, S.M. Wilson, K.S. Abayasiriwardana, R. Collins, L. Fjellbirkeland, Z. Xu, D.M. Jablons, S.L. Nishimura, V.C. Broaddus, A novel in vitro model of human mesothelioma for studying tumor biology and apoptotic resistance, Am. J. Respir. Cell Mol. Biol. 33 (2005) 541-548.

[201] I. Mohiuddin, X. Cao, M.K. Ozvaran, L. Zumstein, S. Chada, W.R. Smythe, Phosphatase and tensin analog gene overexpression engenders cellular death in human malignant mesothelioma cells via inhibition of AKT phosphorylation, Ann. Surg. Oncol. 9 (2002) 310-316.

[202] M.A.S. Cedrés, P. Montero, A. Martinez, V. Martinez, D. Rodríguez-Freixinós, A Torrejon, M. Gabaldon, S. Salcedo, Ramon y Cajal, E. Felip, Exploratory analysis of activation of PTEN-PI3K pathway and downstream proteins in malignant pleural mesothelioma (MPM), Lung Cancer 77 (2012) 192-198(Amsterdam, Netherlands).

[203] L. Zhao, P.K. Vogt, Hot-spot mutations in p110alpha of phosphatidylinosito 3-kinase (pI3K): differential interactions with the regulatory subunit $\mathrm{p} 85$ and with RAS, Cell Cycle 9 (2010) 596-600.

[204] P.K. Vogt, S. Kang, M.A. Elsliger, M. Gymnopoulos, Cancer-specific mutations in phosphatidylinositol 3-kinase, Trends Biochem. Sci. 32 (2007) 342-349.

[205] S. Varghese, Z. Chen, D.L. Bartlett, J.F. Pingpank, S.K. Libutti, S.M. Steinberg, J. Wunderlich, H.R. Alexander, Activation of the phosphoinositide-3-kinase and mammalian target of rapamycin signaling pathways are associated with shortened survival in patients with malignant peritoneal mesothelioma, Cancer 117 (2011) 361-371.

[206] D.A. Fennell, R.M. Rudd, Defective core-apoptosis signalling in diffuse malignant pleural mesothelioma: opportunities for effective drug development, Lancet Oncol. 5 (2004) 354-362.

[207] B. Bedogni, S.M. Welford, A.C. Kwan, J. Ranger-Moore, K. Saboda, M.B. Powell, Inhibition of phosphatidylinositol-3-kinase and mitogen-activated protein kinase kinase $1 / 2$ prevents melanoma development and promotes melanoma regression in the transgenic TPRas mouse model, Mol. Cancer Ther. 5 (2006) 3071-3077.

[208] G.W. Cole, A.M. Alleva, J.T. Zuo, S.S. Sehgal, W.-S. Yeow, D.S. Schrump, D.M. Nguyen, Suppression of Pro-metastasis phenotypes expression in malignant pleural mesothelioma by the PI3K inhibitor LY294002 or the MEK inhibitor UO126, Anticancer Res. 26 (2006) 809-821.

[209] D. Barbone, T.M. Yang, J.R. Morgan, G. Gaudino, V.C. Broaddus, Mammalian target of rapamycin contributes to the acquired apoptotic resistance of human mesothelioma multicellular spheroids, J. Biol. Chem. 283 (2008) 13021-13030.

[210] Z.A. Knight, K.M. Shokat, Chemically targeting the PI3K family, Biochem. Soc. Trans 35 (2007) 245-249.

[211] B.T. Hennessy, D.L. Smith, P.T. Ram, Y. Lu, G.B. Mills, Exploiting the PI3K/AKT pathway for cancer drug discovery, Nat. Rev. Drug Discov. 4 (2005) 988-1004.

[212] L. Yang, H.C. Dan, M. Sun, Q. Liu, X.-m. Sun, R.I. Feldman, A.D. Hamilton, M. Polokoff, S.V. Nicosia, M. Herlyn, S.M. Sebti, J.Q. Cheng, Akt/protein kinase B signaling inhibitor-2, a selective small molecule inhibitor of Akt signaling with antitumor activity in cancer cells overexpressing Akt, Cancer Res. 64 (2004) 4394-4399.

[213] D. Hanahan, R.A. Weinberg, The hallmarks of cancer, Cell 100 (2000) 57-70.

[214] L.E. Leard, V.C. Broaddus, Mesothelial cell proliferation and apoptosis, Respirology 9 (2004) 292-299.

[215] S.R. Narasimhan, L. Yang, B.I. Gerwin, V.C. Broaddus, Resistance of pleural mesothelioma cell lines to apoptosis: relation to expression of Bcl-2 and Bax, Am. J. Physiol. 275 (1998) L165-L171.

[216] L. Zhang, J. Yu, B.H. Park, K.W. Kinzler, B. Vogelstein, Role of BAX in the apoptotic response to anticancer agents, Science 290 (2000) 989-992.

[217] M. Raisova, A.M. Hossini, J. Eberle, C. Riebeling, T. Wieder, I. Sturm, P.T. Daniel, C.E. Orfanos, C.C. Geilen, The Bax/Bcl-2 ratio determines the susceptibility of human melanoma cells to CD95/Fas-mediated apoptosis, J. Invest. Dermatol. 117 (2001) 333-340.

[218] X. Cao, C. Rodarte, L. Zhang, C.D. Morgan, J. Littlejohn, W.R. Smythe, Bcl2/bcl-xL inhibitor engenders apoptosis and increases chemosensitivity in mesothelioma, Cancer Biol. Ther. 6 (2007) 246-252.

[219] S.W. Fesik, Promoting apoptosis as a strategy for cancer drug discovery, Nat. Rev. Cancer 5 (2005) 876-885.

[220] X.X. Cao, I. Mohuiddin, F. Ece, D.J. McConkey, W.R. Smythe, Histone deacetylase inhibitor downregulation of bcl-xl gene expression leads to apoptotic cell death in mesothelioma, Am. J. Respir. Cell Mol. Biol. 25 (2001) 562-568.

[221] W.R. Smythe, I. Mohuiddin, M. Ozveran, X.X. Cao, Antisense therapy for malignant mesothelioma with oligonucleotides targeting the bcl-xl gene product, J. Thorac. Cardiovasc. Surg. 123 (2002) 1191-1198.

[222] J.E. Littlejohn, X. Cao, S.D. Miller, M.K. Ozvaran, D. Jupiter, L. Zhang, C. Rodarte, W.R. Smythe, Bcl-xL antisense oligonucleotide and cisplatin combination therapy extends survival in SCID mice with established mesothelioma xenografts, Int. J. Cancer 123 (2008) 202-208.

[223] E. Varin, C. Denoyelle, E. Brotin, M. Meryet-Figuiã̈re, F. Giffard, E. Abeilard, D. Goux, P. Gauduchon, P. Icard, L. Poulain, Downregulation of Bcl-xL and Mcl-1 is sufficient to induce cell death in mesothelioma cells highly refractory to conventional chemotherapy, Carcinogenesis 31 (2010) 984-993.

[224] X. Cao, J. Yap, M. Newell-Rogers, C. Peddaboina, W. Jiang, H. Papaconstantinou, D. Jupitor, A. Rai, K.-Y. Jung, R. Tubin, W. Yu, K. Vanommeslaeghe, P. Wilder, A. MacKerell, S. Fletcher, R. Smythe, The novel BH3 alpha-helix mimetic JY-1-106 induces apoptosis in a subset of cancer cells (lung cancer, colon cancer and mesothelioma) by disrupting Bcl-xL and Mcl-1 protein-protein interactions with Bak, Mol. Cancer 12 (2013) 42

[225] B.Z. Yuan, J.A. Chapman, S.H. Reynolds, Proteasome inhibitor MG132 induces apoptosis and inhibits invasion of human malignant pleural mesothelioma cells, Transl. Oncol. 1 (2008) 129-140.
[226] K.A. Morrow, L.A. Shevde, Merlin: the wizard requires protein stability to function as a tumor suppressor, Biochim. Biophys. Acta, Rev. Cancer 1826 (2012) 400-406.

[227] S. Tsukita, K. Oishi, N. Sato, J. Sagara, A. Kawai, ERM family members as molecular linkers between the cell surface glycoprotein CD44 and actin-based cytoskeletons, J. Cell Biol. 126 (1994) 391-401.

[228] I. Stamenkovic, Q. Yu, Merlin, a "Magic" linker between the extracellular cues and intracellular signaling pathways that regulate cell motility, proliferation, and survival, Curr. Protein Pept. Sci. 11 (2010) 471-484.

[229] R. Rong, X. Tang, D.H. Gutmann, K. Ye, Neurofibromatosis 2 (NF2) tumor suppressor merlin inhibits phosphatidylinositol 3-kinase through binding to PIKE-L, Proc. Natl. Acad. Sci. 101 (2004) 18200-18205.

[230] M.F. James, S. Han, C. Polizzano, S.R. Plotkin, B.D. Manning, A.O. StemmerRachamimov, J.F. Gusella, V. Ramesh, NF2/Merlin is a novel negative regulator of mTOR complex 1, and activation of mTORC1 is associated with meningioma and schwannoma growth, Mol. Cell. Biol. 29 (2009) 4250-4261.

[231] M. Curto, B.K. Cole, D. Lallemand, C.H. Liu, A.I. McClatchey, Contact-dependent inhibition of EGFR signaling by Nf2/Merlin, J. Cell Biol. 177 (2007) 893-903.

[232] C. Thurneysen, I. Opitz, S. Kurtz, W. Weder, R.A. Stahel, E. Felley-Bosco, Functional inactivation of NF2/merlin in human mesothelioma, Lung Cancer 64 (2009) 140-147(Amsterdam, Netherlands).

[233] T. Yokoyama, H. Osada, H. Murakami, Y. Tatematsu, T. Taniguchi, Y. Kondo, Y, Yatabe, Y. Hasegawa, K. Shimokata, Y. Horio, T. Hida, Y. Sekido, YAP1 is involved in mesothelioma development and negatively regulated by Merlin through phosphorylation, Carcinogenesis 29 (2008) 2139-2146.

[234] C.Y. Logan, R. Nusse, The WNT signaling pathway in development and disease, Annu. Rev. Cell Dev. Biol. 20 (2004) 781-810.

[235] A. Klaus, W. Birchmeier, Wnt signalling and its impact on development and cancer, Nat. Rev. Cancer 8 (2008) 387-398.

[236] B.T. MacDonald, K. Tamai, X. He, Wnt/2 ${ }^{2}$-catenin signaling: components, mechanisms, and diseases, Dev. Cell 17 (2009) 9-26.

[237] A.Y. Lee, B. He, L. You, S. Dadfarmay, Z. Xu, J. Mazieres, I. Mikami, F. McCormick, D.M. Jablons, Expression of the secreted frizzled-related protein gene family is downregulated in human mesothelioma, Oncogene 23 (2004) 6672-6676.

[238] S. Batra, Y. Shi, K.M. Kuchenbecker, B. He, N. Reguart, I. Mikami, L. You, Z. Xu, Y.-C. Lin, G.v. Clément, D.M. Jablons, Wnt inhibitory factor-1, a Wnt antagonist, is silenced by promoter hypermethylation in malignant pleural mesothelioma, Biochem. Biophys. Res. Commun. 342 (2006) 1228-1232.

[239] H. Kohno, V.J. Amatya, Y. Takeshima, K. Kushitani, N. Hattori, N. Kohno, K. Inai, Aberrant promoter methylation of WIF-1 and SFRP1, 2, 4 genes in mesothelioma, Oncol. Rep. 24 (2010) 423-431.

[240] A.S. Abutaily, J.E. Collins, W.R. Roche, Cadherins, catenins and APC in pleural malignant mesothelioma, J. Pathol. 201 (2003) 355-362.

[241] W. Anani, R. Bruggeman, D.S. Zander, Beta-catenin expression in benign and malignant pleural disorders, Int. J. Clin. Exp. Pathol. 4 (2011) 742-747.

[242] S.A. Fox, A.K. Richards, I. Kusumah, V. Perumal, E.M. Bolitho, S.E. Mutsaers, A.M. Dharmarajan, Expression profile and function of Wnt signaling mechanisms in malignant mesothelioma cells, Biochem. Biophys. Res. Commun. 440 (2013) 82-87.

[243] M. Kobayashi, C.L. Huang, M. Sonobe, R. Kikuchi, M. Ishikawa, J. Kitamura, R. Miyahara, T. Menju, S. Iwakiri, K. Itoi, R. Yasumizu, H. Date, Intratumoral Wnt2B expression affects tumor proliferation and survival in malignant pleural mesothelioma patients, Exp. Ther. Med. 3 (2012) 952-958.

[244] J. Mazieres, L. You, B. He, Z. Xu, S. Twogood, A.Y. Lee, N. Reguart, S. Batra, I. Mikami, D.M. Jablons, Wnt2 as a new therapeutic target in malignant pleural mesothelioma, Int. J. Cancer 117 (2005) 326-332.

[245] B. He, L. You, K. Uematsu, Z. Xu, A.Y. Lee, M. Matsangou, F. McCormick, D.M. Jablons, A monoclonal antibody against Wnt-1 induces apoptosis in human cancer cells, Neoplasia 6 (2004) 7-14.

[246] Y. Dai, C.W.M. Bedrossian, C.W. Michael, The expression pattern of $\beta$-catenin in mesothelial proliferative lesions and its diagnostic utilities, Diagn. Cytopathol. 33 (2005) 320-324.

[247] T. Taniguchi, S. Karnan, T. Fukui, T. Yokoyama, H. Tagawa, K. Yokoi, Y. Ueda, T. Mitsudomi, Y. Horio, T. Hida, Y. Yatabe, M. Seto, Y. Sekido, Genomic profiling of malignant pleural mesothelioma with array-based comparative genomic hybridization shows frequent non-random chromosomal alteration regions including JUN amplification on 1p32, Cancer Sci. 98 (2007) 438-446.

[248] N. Usami, T. Fukui, M. Kondo, T. Taniguchi, T. Yokoyama, S. Mori, K. Yokoi, Y. Horio, K. Shimokata, Y. Sekido, T. Hida, Establishment and characterization of four malignant pleural mesothelioma cell lines from Japanese patients, Cancer Sci. 97 (2006) 387-394.

[249] N. Tochigi, R. Attanoos, L.R. Chirieac, T.C. Allen, P.T. Cagle, S. Dacic, p16 deletion in sarcomatoid tumors of the lung and pleura, Arch. Pathol. Lab. Med. 137 (2013) 632-636.

[250] S. Matsumoto, K. Nabeshima, T. Kamei, K. Hiroshima, K. Kawahara, S. Hata, K. Marukawa, Y. Matsuno, K. Taguchi, T. Tsujimura, Morphology of 9p21 homozygous deletion-positive pleural mesothelioma cells analyzed using fluorescence in situ hybridization and virtual microscope system in effusion cytology, Cancer Cytopathol. 121 (2013) 415-422.

[251] J.O. Cheng, W.C. Lee, M.A. Klein, G.Z. Cheng, S.C. Jhanwar, J.R. Testa, Frequent mutations of NF2 and allelic loss from chromosome band 22q12 in malignant mesothelioma: evidence for a two-hit mechanism of NF2 inactivation, Genes Chromosom. Cancer 24 (1999) 238-242.

[252] B. Deguen, L. Goutebroze, M. Giovannini, C. Boisson, R. van der Neut, M.C. Jaurand, G. Thomas, Heterogeneity of mesothelioma cell lines as defined by altered genomic structure and expression of the NF2 gene, Int. J. Cancer 77 (1998) 554-560. 